\title{
Transcriptomic comparison of Aspergillus niger growing on two different sugars reveals coordinated regulation of the secretory pathway
} Thomas R Jørgensen 1,2, Theo Goosen ${ }^{2,3}$, Cees AMJJ van den Hondel2, Arthur FJ Ram*2 and Jens JL Iversen ${ }^{1}$

Address: ${ }^{1}$ Department of Biochemistry and Molecular Biology, University of Southern Denmark, Campusvej 55, 5230 Odense M, Denmark, 2Institute for Biology, Leiden University, Kluyver Centre for Genomics of Industrial Fermentation, Wassenaarseweg 64, 2333 AL Leiden, the Netherlands and ${ }^{3}$ BioCentre, HAN University, Laan van Scheut 2, 6525 EM Nijmegen, the Netherlands

Email: Thomas R Jørgensen - t.r.jorgensen@biology.leidenuniv.nl; Theo Goosen - t.goosen@chello.nl; Cees AMJJ van den Hondel - c.a.m.van.den.hondel@biology.leidenuniv.nl; Arthur FJ Ram* - a.f.j.ram@biology.leidenuniv.nl; Jens JL Iversen - jjli@bmb.sdu.dk * Corresponding author

Published: 23 January 2009

BMC Genomics 2009, 10:44 doi:10.1/86/147|-2164-10-44
Received: 14 October 2008

Accepted: 23 January 2009

This article is available from: http://www.biomedcentral.com/147/-2/64/10/44

(C) 2009 Jørgensen et al; licensee BioMed Central Ltd.

This is an Open Access article distributed under the terms of the Creative Commons Attribution License (http://creativecommons.org/licenses/by/2.0), which permits unrestricted use, distribution, and reproduction in any medium, provided the original work is properly cited.

\begin{abstract}
Background: The filamentous fungus, Aspergillus niger, responds to nutrient availability by modulating secretion of various substrate degrading hydrolases. This ability has made it an important organism in industrial production of secreted glycoproteins. The recent publication of the A. niger genome sequence and availability of microarrays allow high resolution studies of transcriptional regulation of basal cellular processes, like those of glycoprotein synthesis and secretion. It is known that the activities of certain secretory pathway enzymes involved $\mathrm{N}$ glycosylation are elevated in response to carbon source induced secretion of the glycoprotein glucoamylase. We have investigated whether carbon source dependent enhancement of protein secretion can lead to upregulation of secretory pathway elements extending beyond those involved in $\mathrm{N}$-glycosylation.
\end{abstract}

Results: This study compares the physiology and transcriptome of $A$. niger growing at the same specific growth rate $\left(0.16 \mathrm{~h}^{-1}\right)$ on xylose or maltose in carbon-limited chemostat cultures. Transcription profiles were obtained using Affymetrix GeneChip analysis of six replicate cultures for each of the two growth-limiting carbon sources. The production rate of extracellular proteins per gram dry mycelium was about three times higher on maltose compared to xylose. The defined culture conditions resulted in high reproducibility, discriminating even low-fold differences in transcription, which is characteristic of genes encoding basal cellular functions. This included elements in the secretory pathway and central metabolic pathways. Increased protein secretion on maltose was accompanied by induced transcription of $>90$ genes related to protein secretion. The upregulated genes encode key elements in protein translocation to the endoplasmic reticulum (ER), folding, $\mathrm{N}$-glycosylation, quality control, and vesicle packaging and transport between ER and Golgi. The induction effect of maltose resembles the unfolded protein response (UPR), which results from ER-stress and has previously been defined by treatment with chemicals interfering with folding of glycoproteins or by expression of heterologous proteins.

Conclusion: We show that upregulation of secretory pathway genes also occurs in conditions inducing secretion of endogenous glycoproteins - representing a more normal physiological state. Transcriptional regulation of protein synthesis and secretory pathway genes may thus reflect a general mechanism for modulation of secretion capacity in response to the conditional need for extracellular enzymes. 


\section{Background}

The black-spored mitosporic fungus, Aspergillus niger, is specialized to grow on plant cell wall- and storagepolysaccharides such as xylans, pectins, starch and inulin $[1,2]$. It does so by secreting high levels of a wide range of substrate degrading enzymes into its habitat. Enzyme mediated degradation of plant polysaccharides results in liberation of monomeric carbohydrates, which are efficiently taken up and metabolised by the fungus. The inherent high enzyme secretion capacity of $A$. niger and its high productivity of organic acids, like citric acid, has made it an interesting organism to study processes such as protein production and primary metabolism [3,4]. Members of the genus Aspergillus, including A. niger, are also reputed for biosynthetic potential of a variety of mycotoxins [5], such as the carcinogenic aflatoxins [6,7] and ochratoxins [8] and, as discovered recently in A. niger, also the carcinogenic fumonisins [3,9].

In eukaryotic cells, protein secretion involves ER-associated translation, folding and modification of proteins, which are then transported via vesicles to the Golgi apparatus or other compartments for further modification. The mature glycoproteins are finally transported with secretory vesicles to the cell membrane and secreted into the environment. The components and mechanisms of the secretory pathway in eukaryotes are highly conserved. Main elements of the secretory pathway in fungi and mammals are described in recent reviews [10-13]. A genomic comparison of genes encoding secretory pathway components in A. niger, Saccharomyces cerevisiae and mammals has not revealed major differences in the number of genes involved in protein secretion and the analysis did not explain why $A$. niger is a more efficient secretor of extracellular proteins than the yeast $S$. cerevisiae [3]. However, it has been shown that activity of certain secretory pathway enzymes involved $N$-glycosylation is elevated in response to overexpression of the glycoprotein glucoamylase in A. niger [14]. There is also a positive correlation between glucoamylase expression and activity of glycosylation enzymes when comparing growth on maltodextrin, which induces glucoamylase expression, to growth on xylose, which is a non-inducing carbon source [14]. These observations suggest that $A$. niger can adapt the activity of at least parts of its secretory pathway to handle the increased load of secreted proteins induced by a given environment. In the present work, we have investigated whether carbon source dependent enhancement of protein secretion can lead to upregulation of secretory pathway elements, which extend beyond those involved in $N$-glycosylation.

Consequently, we have compared transcriptomic profiles of A. niger cultures, expressing the endogenous glucoamylase gene, growing on a glucoamylase-inducing carbon source, maltose, to profiles from cultures growing on xylose (non-inducing). We have used carbon-limited chemostat cultivation to control the specific growth rate $(\mu)$ during growth on the two different carbon sources and to obtain highest reproducibility in well defined culture conditions.

We show that the rate of protein secretion is 2-3 times higher on maltose compared to xylose, and that the increased protein secretion by $A$. niger on maltose is accompanied by upregulation of transcription of more than 90 genes encoding elements of the secretory pathway. Most of the upregulated secretory pathway elements reside in the ER or are involved in vesicle trafficking between ER and Golgi. The transcriptional response to maltose resembled the unfolded protein response (UPR) induced by diverse types of artificial ER-stress [15]. We suggest that the transcriptional regulation of the secretory pathway is part of a physiological mechanism, which has evolved to allow varying output of substrate degrading enzymes.

\section{Results and discussion Physiology of xylose- or maltose-limited chemostat cultures of $A$. niger}

Steady state cultures, growing on xylose or maltose, were homogenous and characterized by dispersed filamentous hyphae (Fig. 1), and during the whole cultivation only minimal amount of biomass adhered to surfaces in the reactor (< $0.5 \mathrm{~g}$ dry biomass in the end). Carbon was accounted for in carbon balances of the influent medium and effluent culture broth and exhaust gas. The carbonrecoveries were approximately $100 \%$ (Table 1 ), thus validating that $\mu$ was equal to the dilution rate $\left(\mathrm{D}=0.16 \mathrm{~h}^{-1}\right)$ in all 12 steady state cultures. In addition, the relatively large volume (4.3 l) and steady-state biomass concentration of the cultures allowed sampling of sufficient material for analyses without perturbations of the steady state.

Growth physiology of two A. niger strains was evaluated from triplicate chemostat cultures. The duration of initial xylose-grown batch cultures was approximately $21 \mathrm{~h}$, followed by approximately $63 \mathrm{~h}$ of continuous cultivation. After five volume changes $\left(5 \times \mathrm{D}^{-1}\right)$ of xylose-limited growth, the xylose-containing growth medium was replaced with a medium containing maltose. Growth was then followed for another five residence times. As shown in Fig. 2, the shift of carbon source led to a transient decrease of the biomass concentration, indicating that the cells were unable to grow at the same specific growth rate on maltose during the first hour after the shift. Once the metabolic machinery necessary for consumption of maltose was induced, growth rate increased and approximately eight hours after the shift the biomass concentration stabilized at a new steady state value. RNA 
Table I: Physiology in chemostat culture.

\begin{tabular}{|c|c|c|c|c|c|c|c|c|c|c|}
\hline C-source & Strain & $\begin{array}{l}\mathbf{C}_{\text {biomass }} \\
\left(\mathrm{g}_{\mathrm{DW}} \mathrm{kg}^{-1}\right)\end{array}$ & $\begin{array}{c}\mathbf{C}_{\text {xylosel }} \\
\text { maltose }^{\dagger} \\
(\mu \mathrm{M})\end{array}$ & $\begin{array}{c}\mathbf{Y}_{\mathbf{x} / \mathbf{s}} \\
\left(g_{D W}\right. \\
g_{\left.\text {substrate }^{-1}\right)}\end{array}$ & $\begin{array}{c}\mathbf{Y}_{\mathrm{x} / \mathrm{C}} \\
\left(\mathrm{g}_{\mathrm{DW}} \mathrm{g}_{\text {carbon }}\right. \\
-1)\end{array}$ & $\begin{array}{c}\mathrm{qcO}^{\mathrm{co}} \\
\left(\mathrm{mmol} \mathrm{g}^{-1}\right. \\
\left.\mathrm{h}^{-1}\right)\end{array}$ & $\underset{(\mathrm{mmol}}{\mathrm{qO}^{2} \mathrm{~g}}$ & RQ & $\begin{array}{l}\mathbf{q}_{\text {protein-EC }} \\
\left(\mathrm{mg} \mathrm{g}^{-1} \mathrm{~h}^{-1}\right)\end{array}$ & $\begin{array}{c}\text { C- } \\
\text { recovery } \\
(\%)\end{array}$ \\
\hline \multirow[t]{2}{*}{ Xylose } & AB94-85 & $4.06 \pm 0.07$ & $233 \pm 6$ & $0.54 \pm 0.02$ & $1.35 \pm 0.04$ & $3.40 \pm 0.11$ & $3.36 \pm 0.14$ & $1.01 \pm 0.02$ & $0.68 \pm 0.01$ & $98 \pm 2$ \\
\hline & $\begin{array}{l}\text { ABGTI02 } \\
6\end{array}$ & $3.96 \pm 0.07$ & $256 \pm 18$ & $0.53 \pm 0.01$ & $1.32 \pm 0.03$ & $3.41 \pm 0.10$ & $3.42 \pm 0.10$ & $1.00 \pm 0.01$ & $0.72 \pm 0.02$ & $101 \pm 3$ \\
\hline \multirow[t]{2}{*}{ Maltose } & AB94-85 & $\begin{array}{l}3.68 \pm \\
0.08^{*}\end{array}$ & $160 \pm 5$ & $0.52 \pm 0.01$ & $\begin{array}{l}1.23 \pm \\
0.03^{*}\end{array}$ & $\begin{array}{l}2.92 \pm \\
0.05^{*}\end{array}$ & $3.38 \pm 0.14$ & $\begin{array}{l}0.87 \pm \\
0.05^{*}\end{array}$ & $\begin{array}{l}1.98 \pm \\
0.28 *\end{array}$ & $101 \pm 1$ \\
\hline & $\begin{array}{l}\text { ABGTI02 } \\
6\end{array}$ & $\begin{array}{c}3.68 \pm \\
0.12^{*}\end{array}$ & $158 \pm 24$ & $0.52 \pm 0.02$ & $\begin{array}{l}1.23 \pm \\
0.04^{*}\end{array}$ & $\begin{array}{c}2.84 \pm \\
0.17^{*}\end{array}$ & $3.57 \pm 0.27$ & $\begin{array}{c}0.80 \pm \\
0.10^{*}\end{array}$ & $\begin{array}{l}1.69 \pm \\
0.24^{*}\end{array}$ & $97 \pm 2$ \\
\hline
\end{tabular}

Steady state results of chemostat cultures with xylose or maltose as growth-limiting substrates. Standard deviations ( \pm ) are given for mean values of triplicate independent steady state results. $\mathrm{C}_{\text {biomass }}$, dryweight biomass concentration; $\mathrm{C}_{\mathrm{xylose}}$ /maltose, concentration of substrate (NB: maltose as glucose equivalents); $Y_{x s}$, growth yield on substrate; $Y_{x C}$, growth yield on substrate carbon; $q_{c 02}$, specific carbon dioxide evolution rate; $q_{02}$, specific oxygen consumption rate; $\mathrm{RQ}$, respiratory quotient calculated as the ratio of $\mathrm{C}_{\mathrm{O} 2}$ production and $\mathrm{O}_{2}$ consumption rates; $\mathrm{q}_{\text {protein-EC }}$, specific production rate of extracellular protein; C-recovery, carbon recovery. Two-tailed t-tests were used to evaluate significance ( $P<0.05)$ of differences in each column (except substrate concentration and carbon recovery).

* results are significantly different from unmarked results in the same column.

† substrate concentration on maltose is given as concentration of glucose released into filtrate after incubation with $\alpha-g l u c o s i d a s e$.

for transcriptome analysis was isolated from steady state cultures on xylose or maltose after at least four residence times on each carbon source. Growth profiles and sampling events are shown in Fig. 2.

The results listed in Table 1 summarize steady state physiology of xylose- and maltose-limited chemostat cultures. The reproducibility of the triplicate cultures was very high. The coefficient of variation (CV) of steady state biomass concentrations was approximately 0.02 for both carbon sources. While replicate variability was low, there were marked differences between cultures grown on xylose or maltose. Notably, specific productivity of extracellular protein $\left(\mathrm{q}_{\text {protein-EC }}\right)$ was 2 to 3 fold higher on maltose than on xylose, indicating increased protein-secretory activity of maltose-limited cultures. The biomass yield on carbon $\left(\mathrm{Y}_{\mathrm{xC}}\right)$ was lower on maltose, probably at the expense of increased product formation. The carbon concentration in the culture filtrate and the acidification rate of maltoselimited cultures were higher compared to xylose-limited cultures (results not shown). These observations, taken together with a respiratory quotient (RQ) lower than 1 of maltose-limited cultures, most likely reflect higher productivity of organic acids in addition to increased protein secretion on maltose.
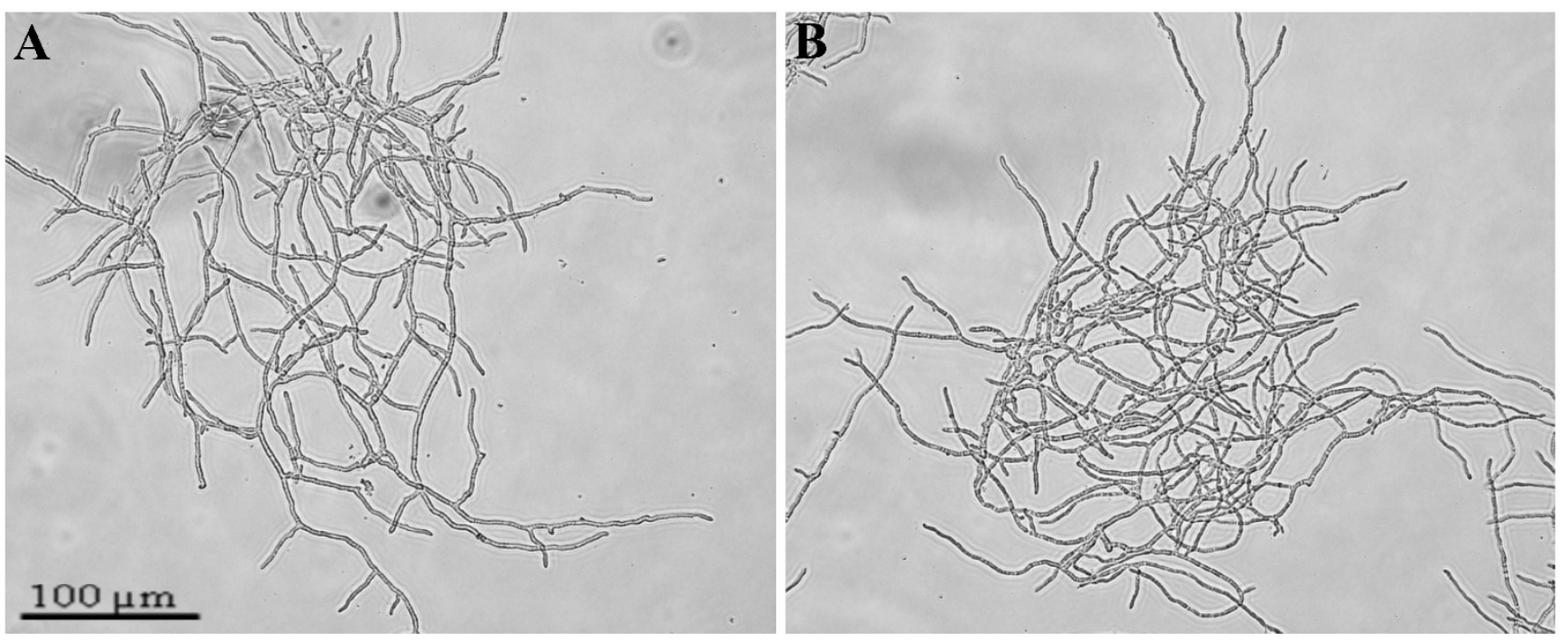

\section{Figure I}

Morphology of mycelium in chemostat cultures of A. niger. (A) Steady state on xylose (50 h). (B) Steady state on maltose $(80 \mathrm{~h})$. 
A

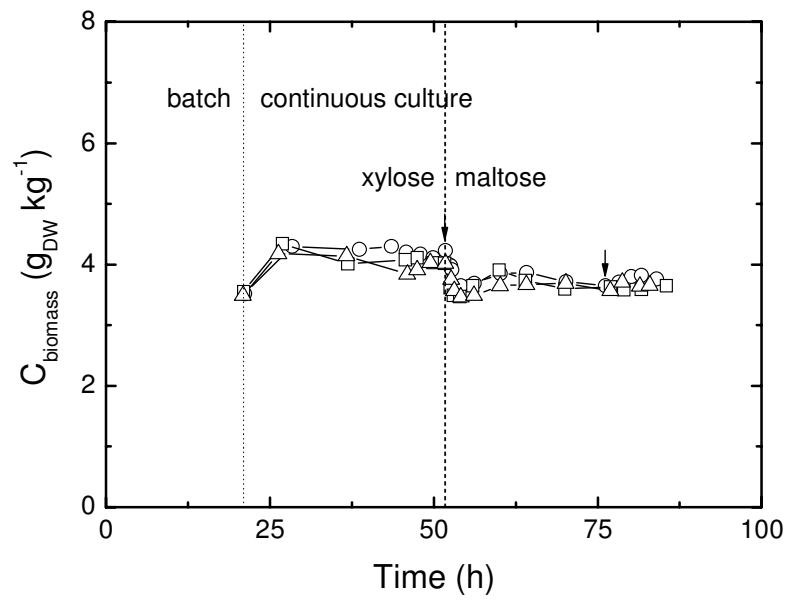

B

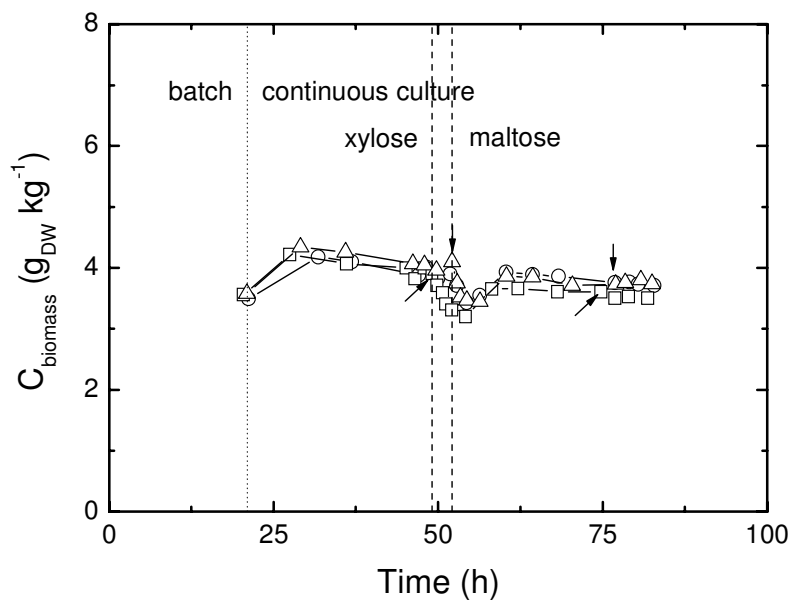

\section{Figure 2}

Growth profiles of triplicate A. niger AB94-85 (A) and ABGTI 026 (B) chemostat cultures, Dry weight biomass concentration $\left(\mathrm{gDW} \mathrm{kg}^{-1}\right)$ as a function of time (h) illustrates growth of three replicate cultures (open square, circle and triangle). Dot-line indicates start of continuous cultivation - exit from batch culture. Dash-line represents the switch to maltose as carbon source after 5 RT with xylose as the growth-limiting substrate. Arrows indicate time-points, where mycelium was harvested for transcriptomic analysis.

\section{Reproducibility of steady state gene-expression}

Microarray analysis revealed, that less than $50 \%$ of the 14,165 predicted open reading frames (ORF) were transcribed on any of the two substrates, xylose or maltose (raw signal intensities and detection calls for all genes are given in [Additional file 1]). The high reproducibility of replicate chemostat cultures was reflected by a very low degree of replicate variation in transcript levels (Fig. 3). The average CV of all genes expressed was $0.14-0.15$ and $0.17-0.22$ in triplicate xylose- and maltose-limited chemostat cultures, respectively. This is fully comparable to the level of reproducibility reported for genome-wide transcription in chemostat cultures of $S$. cerevisiae [16]. A closer look at some (14) of the genes with most variable transcript level on maltose, reveals interesting correlations (Fig. 3B, D). Five of the genes are involved in metabolism/ degradation of xylose or xylans and had varying transcript level in replicate cultures. Transcription of xylose-related genes, in absence of xylose, indicates derepression or influence of previous growth conditions under xyloselimitation, where all five genes were highly expressed. However, after $25 \mathrm{~h}$ or 4 residence times (RT) of continuous cultivation with maltose, more than $98 \%$ of the culture from xylose-limited steady state had been removed and any residual xylose depleted.

Nine other genes with a CV higher than 1 were all more expressed in a replicate culture of AB94-85 (culture "\#95") on maltose. These genes are all part of the putative fumonisin gene cluster in A. niger [3]. In total, twelve genes in the fumonisin gene homolog cluster were expressed on mal- tose [see Additional file 2]. This appears to correspond to all homologous genes needed for biosynthesis of fumonisins in Fusarium verticillioides. Recently, Frisvad et al. [9] reported of fumonisin $\mathrm{B} 2$ production by progenitors of three genome sequenced $A$. niger strains, including the source of the strains in this study (A. niger N400). The variable transcription of homologs in a putative mycotoxin gene cluster demonstrates the need for careful evaluation of a given strain s mycotoxin-producing ability.

\section{Carbon source dependent gene expression}

Analysis of variance (Two-Way ANOVA) identified approximately 1,250 genes differentially expressed (significance: $\mathrm{p}<0.005$ ) in response to the carbon source, xylose or maltose, and independent of strain background [see Additional file 3]. Transcription of $57 \%$ of these were higher on maltose compared to xylose in steady state cultures. Most changes in gene expression were characterized as low-fold differences; for expression of about 890 genes the difference was less than 2-fold. Low-fold differences (< 2) are often precluded from studies due to limitations set by sample size and reproducibility. Generally, one would expect that differences in transcript levels of genes encoding basal functions and elements of basal pathways consisting of many interdependent processes will be small. Transcription of genes encoding functions specific to one condition display high-fold differences, as evidenced by genes involved in conversion of the sole carbon source, xylose, to the pentose phosphate pathway intermediate, xylulose-5-phosphate (Table 2), whereas central metabolic processes, also needed in the other condition 
A

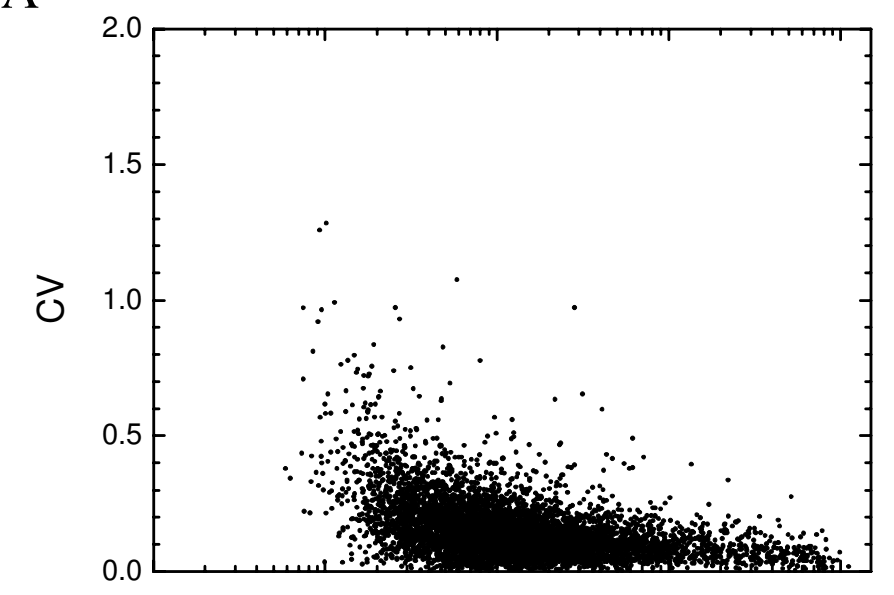

C

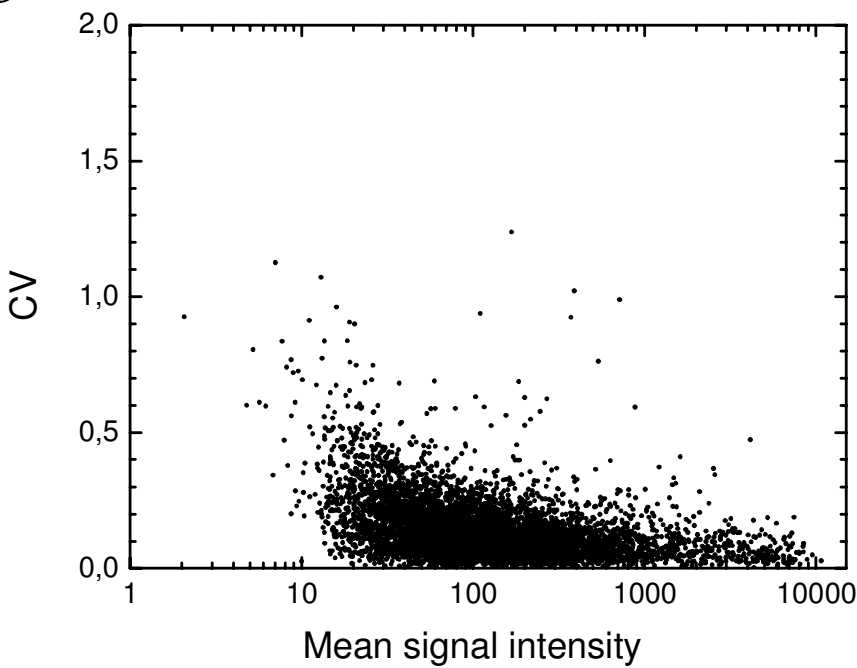

B

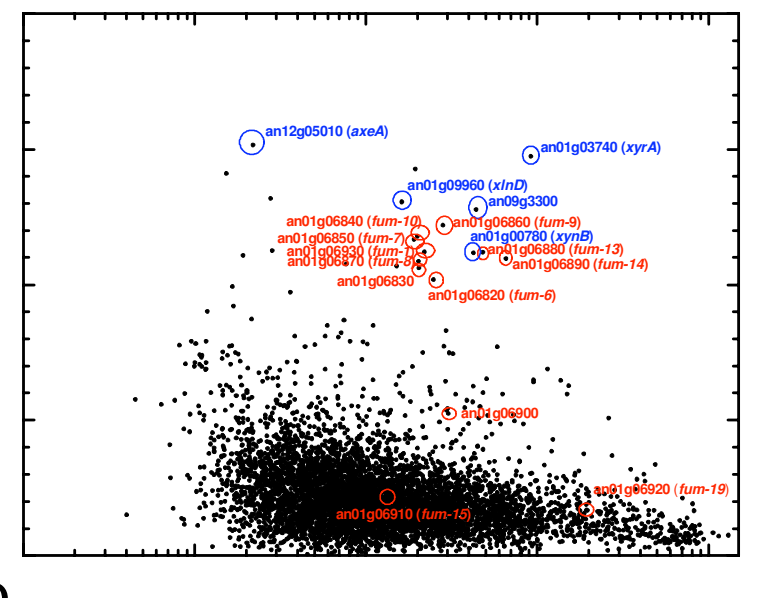

$\mathrm{D}$

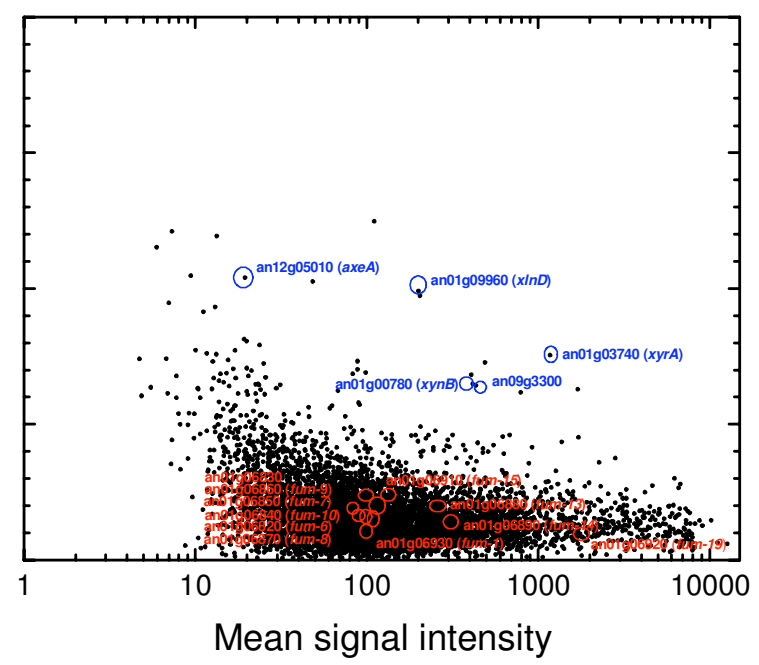

Figure 3

Signal intensity variation among replicate cultures. Variation is expressed as coefficient of variation (CV) of mean signal intensities of independent triplicate measurements, and shown for steady-state gene-expression of xylose- (A, $C)$ and maltoselimited (B, D) cultures of AB94-85 and ABGTI026. Only genes with Detection call Marginal or Present in at least one of three measurements are shown (expressed genes). Blue and red circles and identifiers indicate maltose-expressed genes involved in xylose/xylan catabolism and clustered fumonisin biosynthesis gene homologs, respectively.

(growth on maltose) are characterised by low-fold differences. The latter is exemplified by the low but significant differences in transcription of genes in the pentose phosphate pathway itself (Table 2). Large differences are also found when comparing transcript levels of genes encoding extracellular enzymes, expression of which are specifically induced by particular carbon sources (Table 3 ). Whereas the basal process of protein secretion is governed by a multitude of proteins and protein complexes, many of which are conditionally expressed, but only with small differences in transcript level (Table 4). A solid context of identical specific growth rates has allowed us to study such small, but significant, differences in gene expression between two similar growth conditions. Andersen et al. [4] defined, for three Aspergillus species (incl. A. niger), a conserved transcriptional response to xylose as carbon source compared to glucose (degradation product of maltose). This list does not include pentose phosphate pathway (PPP) genes, showing that the substrate-effect on expression of these genes may be specific for $A$. niger or simply that it is difficult to observe such effects without control of the specific growth rate.

Using the FunCat annotation tool [3,17], an overview of up- or down-regulation of major functional classes during maltose-limitation (compared to xylose-limitation) is 
Table 2: Xylose utilisation metabolic genes with significantly higher expression on xylose compared to maltose.

\begin{tabular}{|c|c|c|c|c|c|c|c|c|c|}
\hline ORF & gene name & encoded enzyme (homolog) & fold difference & signal xylose & SD & Signal maltose & SD & $P$ & FDR \\
\hline \multicolumn{10}{|c|}{ Xylose conversion: } \\
\hline An0Ig03740 & $x y r A$ & D-xylose reductase & 15.9 & 9,267 & 511 & 1,048 & 1,033 & $4.1 \cdot 10^{-3}$ & $4.5 \cdot 10^{-2}$ \\
\hline An07g03140 & & xylulokinase (XksI - S. cerevisiae) & 16.0 & 916 & 103 & 58 & 34 & $2.3 \cdot 10^{-5}$ & $1.3 \cdot 10^{-3}$ \\
\hline \multicolumn{10}{|c|}{ Pentose phosphate pathway - nonoxidative phase: } \\
\hline An08g06570 & & transketolase (TklI - S. cerevisiae) & 1.4 & 5,410 & 439 & 3,522 & 448 & $1.6 \cdot 10^{-4}$ & $4.7 \cdot 10^{-3}$ \\
\hline An07g03850 & & transaldolase (TalI - S. cerevisiae) & 1.4 & 5,127 & 615 & 3,257 & 566 & $1.6 \cdot 10^{-4}$ & $4.7 \cdot 10^{-3}$ \\
\hline An07g03160 & & transaldolase (TalB - Synechocystis sp.) & 8.9 & 551 & 32 & 60 & 26 & $2.1 \cdot 10^{-5}$ & $1.2 \cdot 10^{-3}$ \\
\hline \multicolumn{10}{|c|}{ Glycolysis/gluconeogenesis: } \\
\hline Anl6g05420 & & $\begin{array}{l}\text { glucose-6-phosphate isomerase } \\
\text { (Pgil - S. cerevisiae) }\end{array}$ & 1.7 & $\mathrm{I}, 48 \mathrm{I}$ & 278 & 789 & 61 & $2.5 \cdot 10^{-3}$ & $3.2 \cdot 10^{-2}$ \\
\hline \multicolumn{10}{|c|}{ Pentose phosphate pathway - oxidative phase: } \\
\hline$A n 02 g 12140$ & gsdA & glucose-6-phosphate dehydrogenase & 1.5 & 1,588 & 159 & 966 & III & $4.5 \cdot 10^{-5}$ & $2.0 \cdot 10^{-3}$ \\
\hline
\end{tabular}

ORF = identifier for open reading frame in A. niger CBS5 I 3.88 genome sequence [3]; gene name in A. niger; enzyme encoded by ORF (gene product and species name in parenthesis indicate closest ORF-homolog with characterized function); fold difference reflects ratio of normalized transcript levels on xylose compared to maltose (xylose/ maltose); mean signal values of six experiments on each carbon source and standard deviations (SD) is given in Affymetix units; significance of each observation is given by $\mathrm{P}$ value $(P)$ and the Benjamini-Hochberg false discovery rate (FDR).

given in Fig. 4A. "Metabolism (01)" and "Transport facilitation (67)" were represented as two major functional classes with differentially expressed genes, reflecting need for uptake and metabolism of two different carbon sources. The efficient energy-metabolism on xylose, evident from the high biomass yield and high specific oxygen consumption rate of xylose-limited cultures (Table 1), may be rooted in enhanced expression of genes encoding glucose-6-phosphate dehydrogenase, xylose conversion enzymes and the nonoxidative phase of pentose phosphate pathway (Table 2).

In the carbon metabolism category were also genes encoding secreted carbohydrases (Table 3). Highly expressed genes on maltose include genes encoding the acid amy- lase (AamA), glucoamylase (GlaA) and the alpha-glucosidase (AgdA), enzymes which have also been identified as highly induced genes, when grown on maltose in batch cultures [18]. On maltose, glaA displayed the highest transcript level of all genes. Array signals and Northern blot analysis indicated that probes for glaA were saturated, resulting in an underestimation of fold difference [see Additional file 4]. The list of highly-induced genes on xylose, contains enzymes involved in xylan degradation. Induction of $x \ln D$, eglA and $a g u A$ by xylose in a XlnRdependent way have been described [19]. High expression of axlA on xylose supports its proposed function as an alpha-xylosidase [18]. Strong induction of $x y n B$ on xylose has not been reported before, but its function as an endoxylanase fits well with its expression profile.

Table 3: The 10, most highly and differentially expressed, secreted-carbohydrase genes on xylose or maltose.

\begin{tabular}{|c|c|c|c|c|c|c|c|c|c|}
\hline ORF & gene name & encoded enzyme (homolog) & fold difference & signal xylose & SD & signal maltose & SD & $P$ & FDR \\
\hline \multicolumn{10}{|c|}{ High expression on maltose (maltose/xylose): } \\
\hline An03g06550 & glaA & glucoamylase & 3.5 & 4,175 & 574 & $* 12,892$ & 805 & $1.8 \cdot 10^{-8}$ & $4.5 \cdot 10^{-5}$ \\
\hline An04g06920 & $\operatorname{agdA}$ & extracellular alpha-glucosidase & 25.0 & 468 & 54 & 10,460 & 1,117 & $6.8 \cdot 10^{-12}$ & $8.5 \cdot 10^{-8}$ \\
\hline Anl Ig03340 & $\operatorname{aamA}$ & acid alpha-amylase & 100.5 & 37 & 11 & 3,202 & 356 & $3.6 \cdot 10^{-10}$ & $1.1 \cdot 10^{-6}$ \\
\hline An09g00260 & $a g / C$ & alpha-galactosidase & 4.9 & 450 & 61 & 1,973 & 310 & $1.8 \cdot 10^{-8}$ & $1.4 \cdot 10^{-5}$ \\
\hline An $12 g 08280$ & inul & extracellular exo-inulinase & 25.2 & 57 & 9 & 1,279 & 44 & $9.9 \cdot 10^{-10}$ & $2.4 \cdot 10^{-6}$ \\
\hline \multicolumn{10}{|c|}{ High expression on xylose (xylose/maltose): } \\
\hline An0Ig00780 & $x y n B$ & endo-I,4-xylanase & 22.3 & 7,846 & 1,169 & 422 & 346 & $1.5 \cdot 10^{-4}$ & $4.6 \cdot 10^{-3}$ \\
\hline An0lg09960 & $x \ln D$ & xylosidase & 43.3 & 5,260 & 205 & 182 & 185 & $1.7 \cdot 10^{-4}$ & $5.1 \cdot 10^{-3}$ \\
\hline An $14 g 02760$ & eg/A & endo-glucanase & 81.3 & 4,079 & 476 & 56 & 47 & $4.0 \cdot 10^{-7}$ & $1.1 \cdot 10^{-4}$ \\
\hline An I 4g05800 & aguA & alpha-glucuronidase & 45.0 & 3,619 & 433 & 81 & 45 & $1.4 \cdot 10^{-6}$ & $2.2 \cdot 10^{-4}$ \\
\hline An09g03300 & axIA & alpha-xylosidase & 10.3 & 3,365 & 529 & 438 & 398 & $2.5 \cdot 10^{-3}$ & $3.2 \cdot 10^{-2}$ \\
\hline
\end{tabular}

ORF = identifier for open reading frame in A. niger CBS5 13.88 genome sequence [3]; gene name in A. niger; enzyme encoded by ORF (gene product and species name in parenthesis indicate closest ORF-homolog with characterized function); fold difference reflects ratio of normalized transcript levels (maltose/xylose or xylose/maltose); mean signal values of six experiments on each carbon source and standard deviations (SD) is given in Affymetix units; significance of each observation is given by $p$-value $(p)$ and the Benjamini-Hochberg false discovery rate (FDR).

*signal of An03g06550-probeset appears saturated, leading to underestimation of glaA-transcription in maltose-limited chemostat cultures. 
Table 4: Differential expression of secretory pathway genes.

\begin{tabular}{|c|c|c|c|c|c|}
\hline ORF & gene name & homologous protein in S. cerevisiae & fold difference maltose/xylose & $\mathrm{P}$ & FDR \\
\hline \multicolumn{6}{|c|}{ Translocation to ER: } \\
\hline An07g05800 & & SRP I 4 (YDL092w) - signal recognition particle SU & 1.3 & $1.7 \cdot 10^{-4}$ & $4.9 \cdot 10^{-3}$ \\
\hline An I5g06470* & & signal sequence receptor, $\alpha$ SU (Botryotinia fuckeliana) & 1.7 & $1.6 \cdot 10^{-5}$ & $1.1 \cdot 10^{-3}$ \\
\hline An03g04340 & & SEC6I (YLR378c) - SEC6I complex SU & 1.7 & $2.1 \cdot 10^{-5}$ & $1.2 \cdot 10^{-3}$ \\
\hline An0lgII630* & & SSSI (YDR086c) - SEC6I complex SU & 1.5 & $1.1 \cdot 10^{-3}$ & $1.8 \cdot 10^{-2}$ \\
\hline Anolg13070* & & SEC63 (YOR254c) - SEC63 complex SU & 1.6 & $6.9 \cdot 10^{-5}$ & $2.7 \cdot 10^{-3}$ \\
\hline An02g0I5I0 & & SEC62 (YPL094c) - SEC63 complex SU & 1.7 & $1.5 \cdot 10^{-3}$ & $2.3 \cdot 10^{-2}$ \\
\hline An 16908830* & & SEC66 (YBR I I Iw) - SEC63 complex SU & 1.8 & $3.5 \cdot 10^{-4}$ & $8.3 \cdot 10^{-3}$ \\
\hline \multicolumn{6}{|c|}{ Cleavage of signal sequence: } \\
\hline Anl6g07390 & & SPC2 (YML055w) - signal peptidase complex SU & 1.7 & $2.5 \cdot 10^{-5}$ & $1.4 \cdot 10^{-3}$ \\
\hline An09g05420** & & SPC3 (YLR066w) - signal peptidase complex SU & 1.7 & $2.1 \cdot 10^{-5}$ & $1.2 \cdot 10^{-3}$ \\
\hline AnOlg00560* & & SECII (YIR022w) - signal peptidase complex SU & 1.7 & $1.7 \cdot 10^{-3}$ & $2.5 \cdot 10^{-2}$ \\
\hline \multicolumn{6}{|l|}{ Glycosylation: } \\
\hline Anl 6g04330 & & DPMI (YPRI83w) - dolichol phosphate mannose synthase & 1.6 & $2.3 \cdot 10^{-5}$ & $1.3 \cdot 10^{-3}$ \\
\hline AnI4g00270 & & dolichyl-phosphate mannosyltransferase (B. fuckeliana) & 1.4 & $7.5 \cdot 10^{-4}$ & $1.4 \cdot 10^{-2}$ \\
\hline An03g04410** & & ALG5 (YPL227c) - dolichyl-phosphate glucosyltransferase & 1.6 & $2.8 \cdot 10^{-4}$ & $7.2 \cdot 10^{-3}$ \\
\hline $\mathrm{An} 02 \mathrm{~g} 03240 *$ & & ALG7 (YBR243c) - N-acetyl-glucosaminephosphotransferase & 1.7 & $2.2 \cdot 10^{-4}$ & $6.0 \cdot 10^{-3}$ \\
\hline An 14 g05910* & & ALG2 (YGL065c) - mannosyltransferase & 1.9 & $1.3 \cdot 10^{-3}$ & $2.1 \cdot 10^{-2}$ \\
\hline An04g03130 & & mannose-phosphate-dolichol utilization protein (Mus musculus) & 1.6 & $2.1 \cdot 10^{-4}$ & $5.7 \cdot 10^{-3}$ \\
\hline An08g07020 & & ALG9 (YNL219c) - mannosyltransferase & 1.4 & $4.2 \cdot 10^{-3}$ & $4.6 \cdot 10^{-2}$ \\
\hline An02g 12630 & & ALG6 (YOR002w) - glucosyltransferase & 1.3 & $1.7 \cdot 10^{-3}$ & $2.5 \cdot 10^{-2}$ \\
\hline An02g l4940* & & RFTI (YBL020w) - flippase & 1.5 & $7.6 \cdot 10^{-5}$ & $2.8 \cdot 10^{-3}$ \\
\hline An02g 14560* & & $\begin{array}{l}\text { OSTI (YJL002c) - oligosaccharyltransferase complex, } \\
\alpha \text { SU }\end{array}$ & 1.7 & $1.7 \cdot 10^{-4}$ & $5.0 \cdot 10^{-3}$ \\
\hline An07g04190* & & $\begin{array}{l}\text { WBPI (YEL002c) - oligosaccharyltransferase complex, } \\
\beta S U\end{array}$ & 1.7 & $1.2 \cdot 10^{-4}$ & $3.8 \cdot 10^{-3}$ \\
\hline An I8g03920* & & $\begin{array}{l}\text { OST2 (YOR I 03c) - oligosaccharyltransferase complex, } \\
\varepsilon S U\end{array}$ & 1.5 & $1.4 \cdot 10^{-4}$ & $4.4 \cdot 10^{-3}$ \\
\hline An02gl4930 & & $\begin{array}{l}\text { OST3 (YOR085w) - oligosaccharyltransferase complex, } \\
\gamma \text { SU }\end{array}$ & 1.5 & $9.7 \cdot 10^{-5}$ & $3.4 \cdot 10^{-3}$ \\
\hline An I 6g08570 & & $\begin{array}{l}\text { STT3 (YGL022w) - oligosaccharyltransferase complex, } \\
\text { SU }\end{array}$ & 1.7 & $4.1 \cdot 10^{-5}$ & $1.9 \cdot 10^{-3}$ \\
\hline An04g06990 & & MNSI $(Y J R I 3 \mid w)$ - class I $\alpha$-mannosidase & 1.3 & $2.0 \cdot 10^{-3}$ & $2.8 \cdot 10^{-2}$ \\
\hline An06g01510 & & class I $\alpha$-mannosidase (Aspergillus fumigatus) & 1.7 & $2.1 \cdot 10^{-4}$ & $5.7 \cdot 10^{-3}$ \\
\hline AnI2g00340 & & ER glucosyl hydrolase, Edem (A. fumigatus) & 1.4 & $1.0 \cdot 10^{-3}$ & $1.7 \cdot 10^{-2}$ \\
\hline An07g04940 & & HOCI (YJR075w) - $\alpha-1,6-$ mannosyltransferase & 1.5 & $1.9 \cdot 10^{-5}$ & $1.2 \cdot 10^{-3}$ \\
\hline Anl6g08490 & & PMT4 (YJR I 43c) - O-mannosyltransferase & 1.3 & $1.5 \cdot 10^{-4}$ & $4.7 \cdot 10^{-3}$ \\
\hline AnI5g04810 & & MNT2 (YGL257c) - $\alpha-1,3-$ mannosyltransferase & 0.7 & $1.4 \cdot 10^{-3}$ & $2.2 \cdot 10^{-2}$ \\
\hline An08g04450 & & GDAI (YEL024w) - guanosine diphosphatase & 1.3 & $7.7 \cdot 10^{-4}$ & $1.4 \cdot 10^{-2}$ \\
\hline \multicolumn{6}{|l|}{ Folding: $\quad$} \\
\hline An02gl 4800** & pdiA & PDII (YCL043c) - protein disulfide isomerase & 1.8 & $1.1 \cdot 10^{-5}$ & $3.6 \cdot 10^{-3}$ \\
\hline An02g05890 & epsA & thioredoxin domain protein, TXNDC5 (Homo sapiens) & 1.3 & $1.3 \cdot 10^{-3}$ & $2.1 \cdot 10^{-2}$ \\
\hline Anl8g02020* & tigA & protein disulfide isomerase & 1.6 & $2.3 \cdot 10^{-4}$ & $6.1 \cdot 10^{-3}$ \\
\hline An0lg04600** & prpA & MPDI (YOR288c) - protein disulfide isomerase & 1.9 & $6.0 \cdot 10^{-4}$ & $1.2 \cdot 10^{-2}$ \\
\hline Anl6g07620** & & EROI (YMLI30c) - thiol oxidase & 1.5 & $3.1 \cdot 10^{-3}$ & $2.1 \cdot 10^{-2}$ \\
\hline An 18g04260** & & HUTI (YPL244c) - UDP-galactose transporter & 1.6 & $1.5 \cdot 10^{-4}$ & $4.6 \cdot 10^{-3}$ \\
\hline An08g07810 & & FADI (YDL045c) - FAD synthase & 1.3 & $1.3 \cdot 10^{-3}$ & $2.1 \cdot 10^{-2}$ \\
\hline Anl Ig04I80** & bipA & KAR2 (YJL034w) - ER chaperone & 2.2 & $5.0 \cdot 10^{-5}$ & $2.2 \cdot 10^{-3}$ \\
\hline Anl8g06470 & & ERJ5 (YFR04IC) - ER located DNA-J protein & 1.5 & $3.4 \cdot 10^{-4}$ & $8.2 \cdot 10^{-3}$ \\
\hline AnOlgl $3220^{* * *}$ & & LHSI (YKL073w) - ER lumen Hsp70 chaperone & 1.9 & $2.8 \cdot 10^{-4}$ & $7.1 \cdot 10^{-3}$ \\
\hline An0Ig06670 & & FPR2 (YDR5 I9w) - peptidyl-prolyl isomerase & 1.7 & $1.9 \cdot 10^{-3}$ & $2.7 \cdot 10^{-2}$ \\
\hline \multicolumn{6}{|c|}{ Trimming and quality control of $\mathrm{N}$-glycosylated folded proteins: } \\
\hline AnI5g0I420* & & CWH4I (YGL027c) - alpha glucosidase I & 1.7 & $3.3 \cdot 10^{-6}$ & $3.8 \cdot 10^{-4}$ \\
\hline An09g05880 & & ROT2 (YBR229c) - glucosidase II, $\alpha$ SU & 1.5 & $1.1 \cdot 10^{-5}$ & $8.5 \cdot 10^{-4}$ \\
\hline An I3g00620* & & GTBI (YDR22 I w) - glucosidase II, $\beta$ SU & 1.7 & $2.6 \cdot 10^{-5}$ & $1.4 \cdot 10^{-3}$ \\
\hline Anolg08420** & $c l x A$ & CNEI (YAL058w) - calnexin & 2.3 & $6.5 \cdot 10^{-6}$ & $5.8 \cdot 10^{-4}$ \\
\hline \multicolumn{6}{|c|}{ Vesicular transport of proteins between ER and Golgi: } \\
\hline An04g00360 & & SECI3 (YLR208w) - COPII complex SU & 1.4 & $2.2 \cdot 10^{-5}$ & $1.3 \cdot 10^{-3}$ \\
\hline $\mathrm{An} 02 \mathrm{~g} 01690$ & & SEC3I (YDLI95w) - COPII complex SU & 1.6 & $2.7 \cdot 10^{-4}$ & $7.0 \cdot 10^{-3}$ \\
\hline An08g10650 & & SEC24 (YILI09c) - COPII complex SU & 1.5 & $1.6 \cdot 10^{-3}$ & $2.3 \cdot 10^{-2}$ \\
\hline
\end{tabular}


Table 4: Differential expression of secretory pathway genes. (Continued)

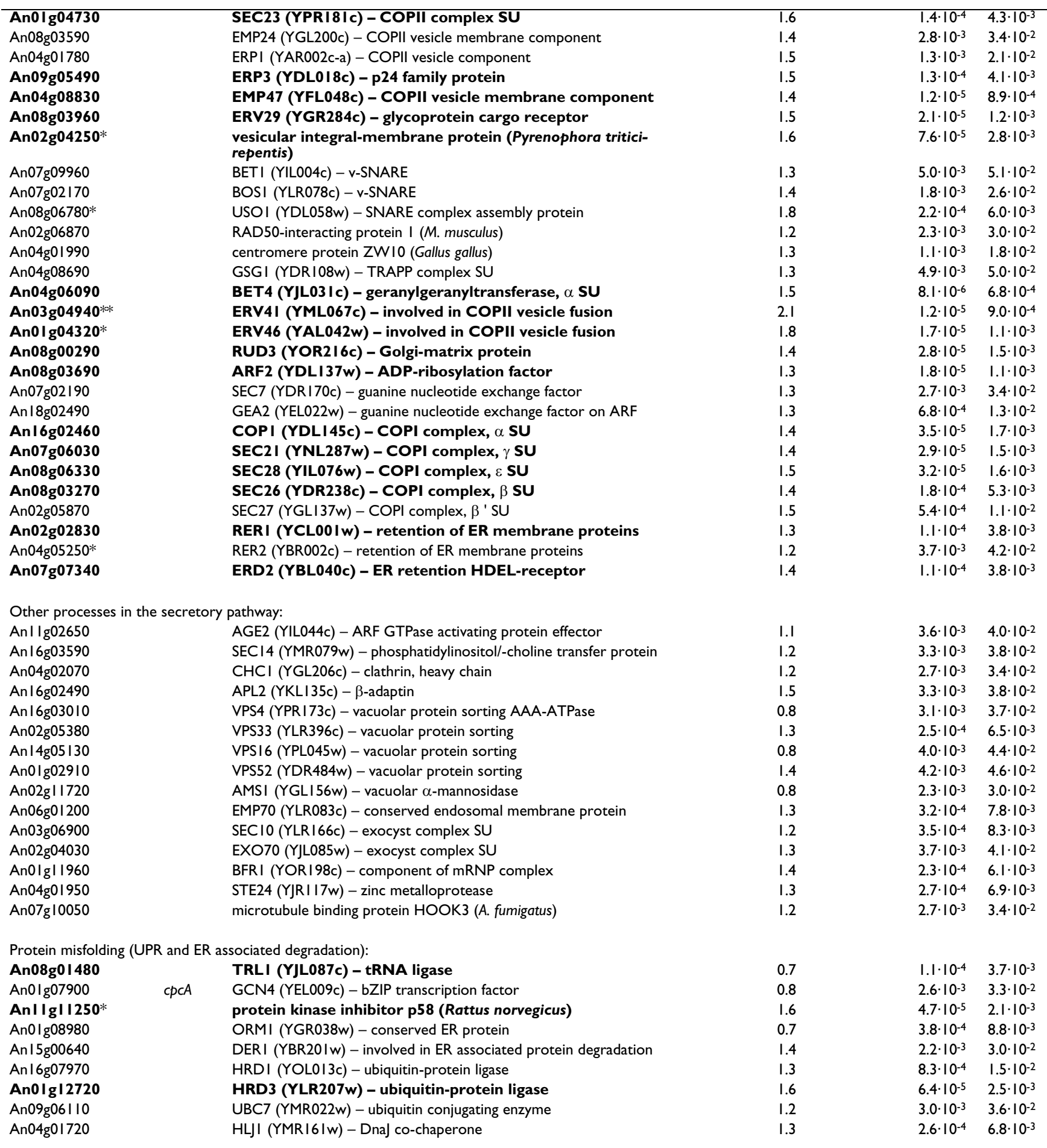

ORF = identifier for open reading frame in A. niger CBS513.88 genome sequence [3]; gene name in A. niger; protein encoded by ORF-homolog in S. cerevisiae and yeast protein function if available; fold difference reflects ratio of normalized transcript levels on maltose compared to xylose (maltose/xylose); significance of each observation is given by p-value ( $\mathrm{P}$ ) and the Benjamini-Hochberg false discovery rate (FDR).

Bold indicates observations with very high significance (FDR $\leq 0.005$ )

$*$ and $* *$ denote genes with increased transcription during ER-stress with 2/3 or 3/3 types of protein folding stress [15], repectively. 


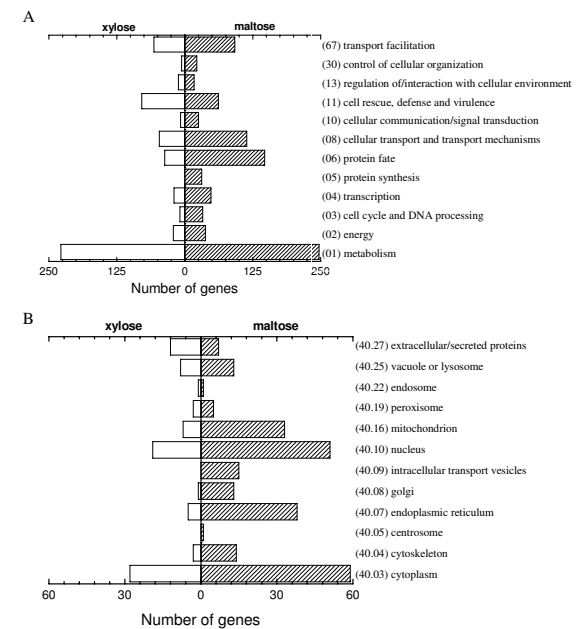

\section{Figure 4}

Functional classification of differentially expressed genes (open bars indicate number of genes with higher transcript levels on xylose; hatched bars represent genes higher expressed on maltose). (A) Representation of major functional categories (Funcat) among differentially expressed genes. (B) Subcellular localization of differentially expressed genes. Unclassified ORFs: high on xylose, 40\% (2I3/528); high on maltose, 30\% (2I4/7/2).

Lipid and sterol biosynthesis and fatty acid metabolic genes also constituted a large group in differentially expressed metabolic genes [Additional file 5]. Perhaps most striking in this group, was the 12-fold increase in transcript level on maltose of a highly expressed and apparently secreted lipase $\left(\right.$ An 16g01880; FDR $\left.=2.9 \cdot 10^{-4}\right)$. In general, several genes involved in biosynthesis of ergosterol and phospholipids were upregulated on maltose, while inositol and choline biosynthesis genes were downregulated. Among these genes, we find a homolog of ino1 (An10g00530), encoding inositol-1-phosphate synthase, a key enzyme in inositol biosynthesis in S. cerevisiae. The differential expression of genes in this category indicate changes (proliferative and/or compositional) in membrane components or energy storage. Intermediates of phospholipid and inositol metabolic pathways also play important roles in cell signalling and global regulatory pathways [20].

"Protein fate (06)" and "Cellular transport and transport mechanisms (08)" comprise most genes of the secretory pathway, and were the second and third largest functional categories of genes with higher transcript level on maltose than on xylose (Fig. 4A). "Subcellular localization (40)" also points to maltose-induced upregulation of the secretory pathway, since many genes are associated with organelle compartments, like the ER, Golgi, transport vesicles, nuclei and mitochondria (Fig. 4B). Subcategories in
Fig. 5(A, B) clearly illustrate the uniform upregulation of genes in secretory processes on maltose compared to xylose. Genes in "Protein synthesis (05)" were only upregulated on maltose. Among these are several genes involved in ribosome biogenesis, translation initiation and polypeptide elongation (Fig. 5C and [Additional file 6]). Thus, the FunCat overview reveals that upregulation of genes involved in protein synthesis and secretion on maltose is a major difference between the two substrates.

\section{Maltose induces expression of secretory pathway genes}

Maltose induces transcription of at least 90 defined secretory pathway genes (Table 4), consistent with higher productivity of extracellular protein and very high expressionlevel of glucoamylase observed in maltose-limited chemostat cultures (Table 1 and 3 ). We could only identify a few genes (six) in the secretory pathway, which were higher expressed on xylose (Table 4). Among the genes with most significant (FDR $\leq 0.005$ ) higher transcript level on maltose are those encoding essential subunits of the Sec61/-63 translocation complex; subunits of the signal peptidase complex; $N$-glycosylation enzymes like dolichol-phosphate-mannosyl flippase and most subunits of the oligosaccharyltransferase (OST) complex; important chaperones and foldases (bipA, pdiA and $c l x A$ ) with well characterized functions in $A$. niger $[10,21,22]$; calnexin $(c l x A)$ is involved in folding and quality control of $N$-glycosylated proteins together with glucosidase I and II, which also display some of the most significant upregulation. The transcriptomic profiles support the recent phylogenetic prediction [18] that An09g05580 encodes the alpha subunit of glucosidase II; since the significance, fold difference (maltose/xylose) and expression level of this ORF is almost identical to the known beta-subunit, while these variables are quite different in the five other candidate ORFs given by Pel et al. [3]. ER-associated degradation (ERAD) is represented among genes with maltose-induced transcription. ER to Golgi vesicular transport of glycosylated proteins is upregulated on maltose, shown by higher transcript levels of genes encoding key COPII coat proteins and lectin cargo receptor proteins.

Genes involved in retrograde vesicular transport (COPI coatamers) and recycling of ER proteins are also higher expressed, and together with upregulation of ER associated degradation (ERAD) of glycoproteins genes, this suggest a general increase in capacity of at least the ER related processes in the secretory pathway. The functions, upregulated during higher protein secretion on maltose, are thus mainly localised in the proximal part of the secretory pathway. Whereas, there was little differential expression of genes encoding components in the more distal parts of the secretory pathway, i.e. trans-Golgi, late secretory vesicles and exocytosis, and endocytosis (Table 4). 
It has been suggested, that efficient protein secretion in filamentous fungi may be obtained through existence of alternative secretory pathways [23]. Our study, on the other hand, suggests that $A$. niger can adapt the secretory capacity by transcriptional regulation of central processes in synthesis, folding and transport of glycoproteins to permit efficient secretion of extracellular proteins, like e.g. glucoamylase (even at wild type levels of secretion). This conclusion is consistent with the observation that the activities of three $\mathrm{N}$-glycosylation enzymes $(\mathrm{N}$-acetylglucosaminyl phosphate transferase, dolichol phosphoglucosyl synthase and dolichol phosphomannosyl synthase) are 2-3 folds higher at growth on maltose-containing medium (maltodextrin) of a glucoamylase hyper-producing A. niger strain compared to a wild type strain [14]. Furthermore, the hyper-producing strain displays wild type activity (low) of $\mathrm{N}$-acetylglucosaminyl phosphate transferase, when both strains are cultivated on xylose [14], which is non-inducing for glaA expression. Some notable analogies to maltose-induction of secretory pathway genes and glaA expression in A. niger were observed by Saloheimo et al. [24] in the filamentous fungus Trichoderma reesei. They showed that expression of pdi- 1 is induced by cellulose and that this correlates with increased expression of cellulase genes and secretion of their gene-products. In mammals it has been observed that glucose induces expression of several secretory pathway genes in pancreatic $\beta$-cells [25]. Furthermore, differentiation into a dedicated secretory cell (e.g. a plasma cell), involves concerted transcriptional upregulation of the secretory pathway via the unfolded protein response (UPR). This phenomenon has been termed a physiological UPR. It is mediated by the master regulator of secretion, Xbp1, which is an ortholog of the Hac1 UPR-regulator in fungi $[26,27]$. From the functional classification and subcellular localization of differentially expressed genes, it is concievable that similar changes take place in the maltose-limited cultures of $A$. niger.

\section{Comparison with ER-stress and UPR in fungi}

In $S$. cerevisiae, the UPR effect on gene transcription has been described for induction with the chemical ER-stressors, DTT and tunicamycin [28], and forced expression of the active form of the UPR transcription factor, Hac1p [29]. A common response to ER-stress in yeast and growth on maltose (this study), is transcriptional upregulation of genes involved in ER-associated processes, such as translocation, $\mathrm{N}$-glycosylation, ERAD and anterograde vesicle transport. The present study even adds to the list of ERassociated genes which are upregulated in response to increased load on the secretory pathway (Table 4). Kitama et al. [29] reported that the UPR led to down-regulation of 15 genes. Of these, a ferrous iron transporter homolog (An01g08960) was significantly lower expressed on maltose (fold difference maltose $/$ xylose $=0.07, \mathrm{FDR}=3.7 \cdot 10^{-}$ $\left.{ }^{4}\right)$.
UPR in S. cerevisiae does not seem to induce transcription of genes involved in trimming and quality control of glycoproteins or in retrograde vesicular transport of proteins from Golgi to ER [28,29]. Travers et al. [28] suggested, that this observation indicates that the UPR in $S$. cerevisiae functions to relieve stress - not to mediate a general increase in secretion capacity. This is in contrast to the present study, where calnexin, subunits of glucosidase I and II and several genes involved in retrograde transport were consistently upregulated during growth on maltose (Table 4). A common theme of the UPR is also changes in transcription of lipid and inositol metabolism. Although growth on maltose led to many significant changes in transcription of both lipid and inositol pathway genes, the changes did not resemble those induced by UPR in $S$. cerevisiae $[28,29]$. Transcription of ino1 was upregulated during constitutive Hac1p-induced UPR [29], while the homolog (An10g00530) of this gene was down-regulated in A. niger growing on maltose. However, similar observations of ino1 transcription have been made in S. cerevisiae strains with secretory pathway defects, which induce the UPR [30].

A recent extensive study of the UPR in A. niger [15] defined common transcriptional responses to treatment with the chemicals, tunicamycin or DTT, and forced secretion of a heterologous protein; conditions, which lead to accumulation of unfolded proteins and ER-stress. The three types of ER-stress induced expression of many genes encoding major functions in the secretory pathway. The 11 genes induced by all three ER-stress conditions [15] were all higher expressed on maltose in this study. In fact, of the genes listed in Table 4, 29 are represented in the list of 34 secretory pathway genes induced by two or all three of the above mentioned stress conditions. Comparing the functions encoded by the ER-stress-induced genes to those with increased expression on maltose, we find that most of the 29 genes are involved in processes early in the protein secretion pathway. These functions are similar to the yeast UPR response and encompass subunits of the translocation complex, signal peptidase, $\mathrm{N}$-glycosylation proteins, foldases and chaperones. In addition to the yeast profiles, calnexin and glucosidase I and II subunits were also upregulated by ER-stress in A. niger. Interestingly, a homolog (An11g11250) of the mammalian interferon induced protein kinase, p58 $8^{\mathrm{IPK}}$, was significant higher expressed both on maltose (Table 4) and in two of the three previously described ER-stress conditions [15]. In mammals, Xbp1 enhances expression of p58 IPK. This has been suggested as a mechanism to antagonise PERK-mediated repression of global protein synthesis during physiological UPR in secretory cells [26]. A. niger lacks an obvious homolog of PERK. It consequently seems probable, that the target of the $\mathrm{p} 58^{\mathrm{IPK}}$-like protein is a homolog of another mammalian protein kinase, like PKR (in Homo sapiens) [31]. The protein encoded by the A. niger PKR- 
A

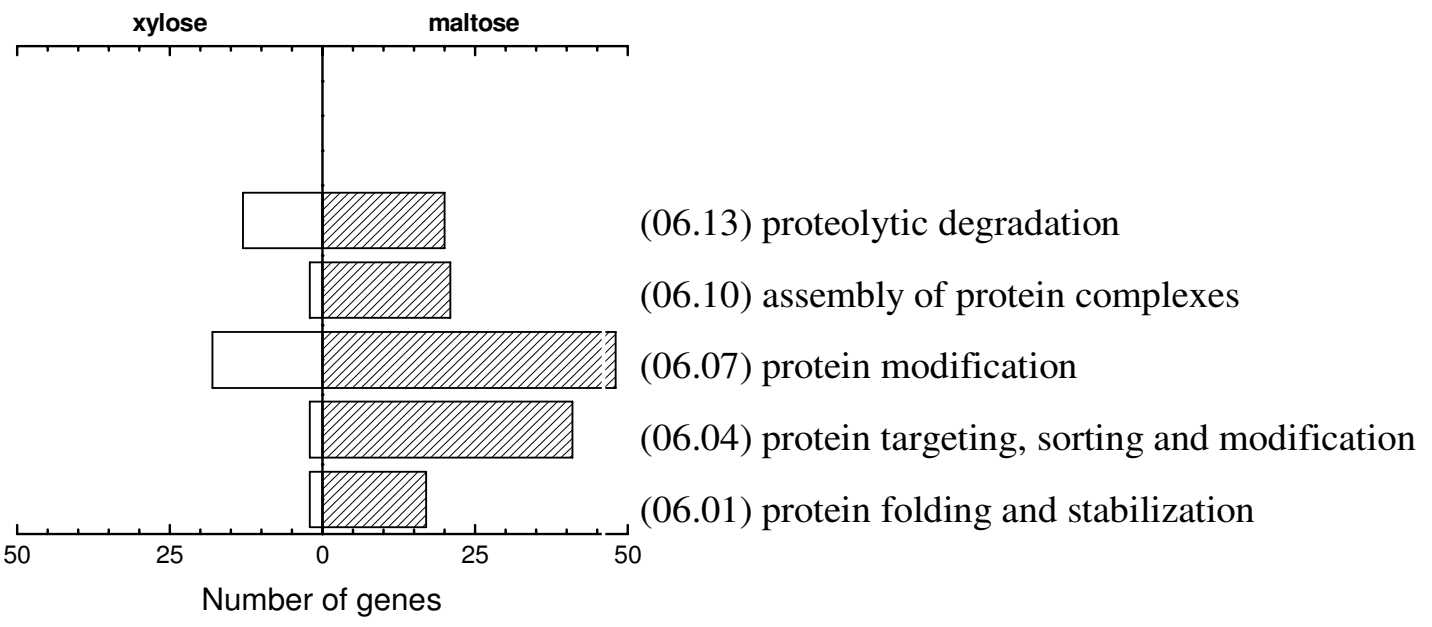

B

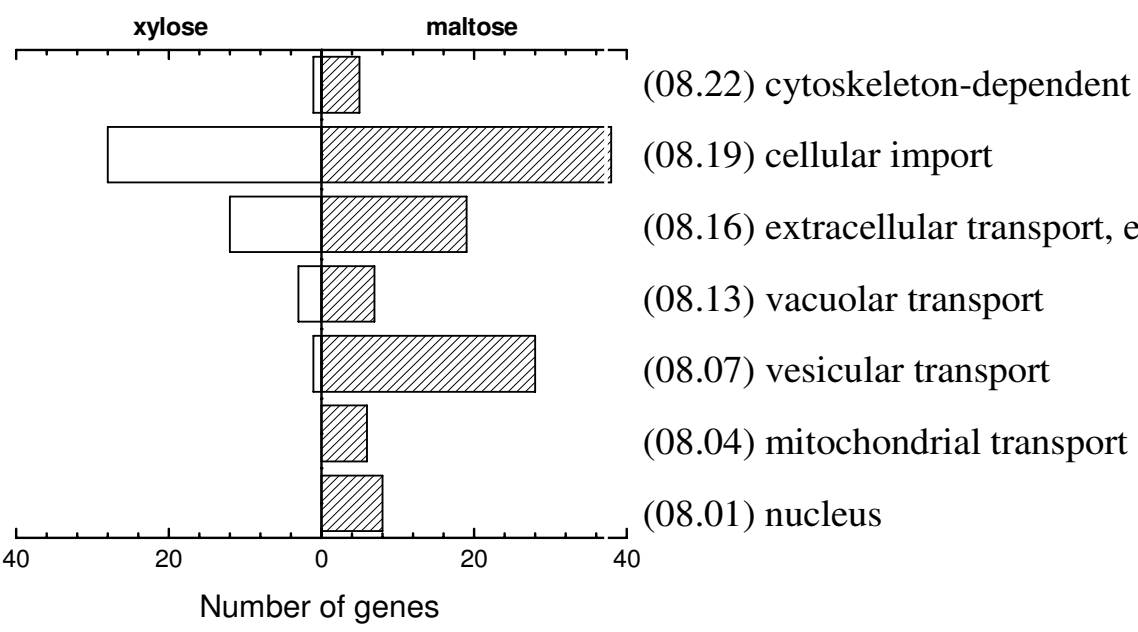

$\mathrm{C}$

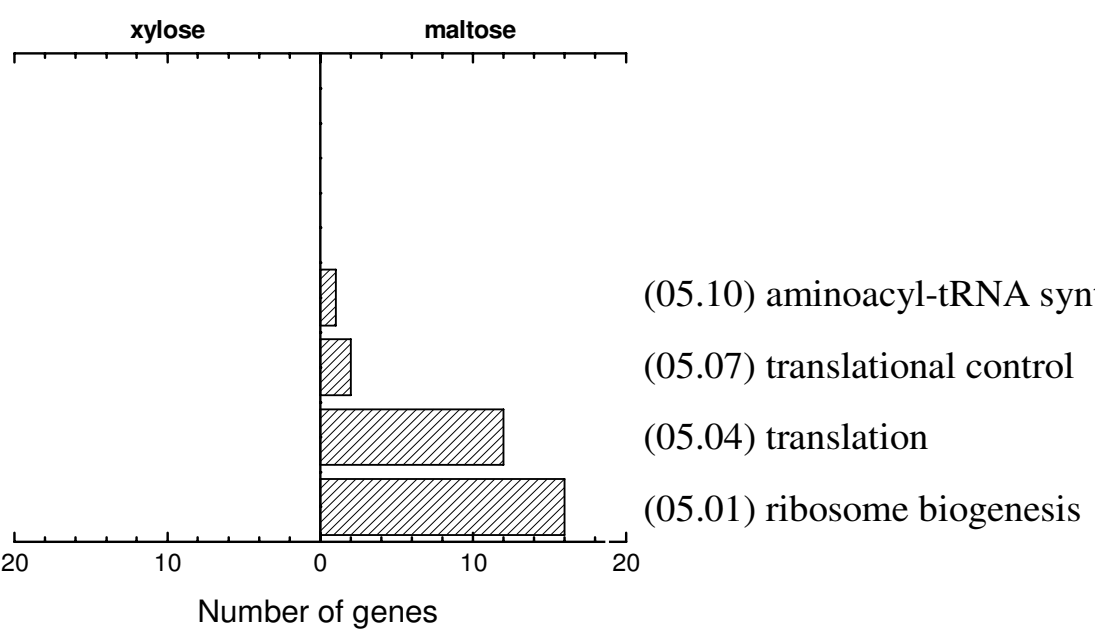

Figure 5

Differentially expressed genes in sub-Funcats of Fig. 4A. (A) 06 - Protein fate. (B) 08 - Cellular transport and transport mechanisms. (C) 05 - Protein synthesis. 
homolog (An17g00860) has high identity (31\% over 1682 residues) to the protein kinase, Gcn2p, in S. cerevisiae. It has been shown in other ascomycete fungi, that Gcn2p homologs have roles in regulation of global protein synthesis and cell cycle progression [32,33]. It is tempting to speculate that $\mathrm{p} 58^{\mathrm{IPK}}$ in $A$. niger can exert derepression of protein synthesis through a homolog of Gcn2p. In S. cerevisiae, Gcn2p plays additional role as a positive regulator of translation of the amino acid starvation transcription factor Gcn $4 p$, which apparently regulates transcription of many UPR induced genes [34]. In our study, CpcA (An01g07900), a homolog of Gcn4p, was down-regulated on maltose, much in contradiction with its putative function as positive regulator of transcription of several UPR target genes in the secretory pathway. The differential expression of key elements of the UPR, such as homologs of p58 IPK and Gcn4p (CpcA), suggests that upregulation of the secretory pathway on maltose occurs via Gcn4p-independent mechanisms.

There were clear differences between the UPR induced by artificial ER-stressors [15], and the physiological response to maltose. For example, during artificially induced ERstress, very few genes, encoding ERAD, COPII and especially COPI vesicular transport proteins, were commonly upregulated. Guillemette et al. [15] also observed changes in expression of fatty acid and lipid metabolism genes. One gene (An02g13420) with similarity to an acetylcoenzyme A transporter was consistently upregulated in all three stress conditions and during growth on maltose; again indicating relation between lipid metabolism and the secretory pathway. This similarity is in contrast to the remaining of the differentially expressed genes in this category; of the seven genes down-regulated by ER-stress we observed four upregulated on maltose. This included the on maltose highly-expressed, secreted or organelle-associated, lipase (An16g01880). This gene was upregulated during ER-stress caused by expression of a heterologous protein, but not in presence of DTT or tunicamycin [15]. A homolog of erg24, a gene involved in ergosterol biosynthesis in S. cerevisiae, was opposite many other putative ergosterol biosynthesis genes down-regulated on maltose, and its transcription was also lower during expression of the heterologous protein [15]. This shows that although the ER-stress responses share a core of similarly expressed functions, expression of other functions are specific to the nature of the ER-stress.

\section{UPR - part of a differentiation programme in development of high secretion capacity?}

Despite many similarities to the fungal ER-stress responses defined by treatment with harsh chemicals or constitutive active expression of the UPR transcription factor, Hac1, or of heterologous proteins, the physiological state of the fungal cells in our study was very different as maltose induced overall protein secretion and transcription of highly expressed hydrolases. Notably, differences in expression of genes in lipid metabolism and in protein synthesis show clear differences between maltose-induced transcription of secretory pathway genes and the chemical-induced UPR. This indicates that what looks like a response to secretion stress, may reflect a more general mechanism not only to alleviate accumulation of unfolded proteins in more extreme conditions, but also to modulate secretion capacity in response to the conditional need for extracellular enzymes. The higher expression level of secretory pathway genes on maltose resembles physiological UPR as described in mammalian cells with high secretion activity a feature which could partly explain why filamentous fungi are efficient enzyme secretors. However, the HacA transcription factor is an integral part of the UPR, and simple evaluation of splicing of HacA mRNA, using RT-PCR [Additional file 7], did not reveal a difference between growth on maltose or xylose nor was there any difference in transcription of hacA. This indicates that the carbon source dependent differential expression of secretory pathway genes involves additional factors than HacA.

This investigation not only presents supporting evidence for a concerted transcriptional regulation of many secretory pathway genes, but also a challenging task with respect to identification of key regulators. Regulatory elements of basal cellular processes may be involved, as many genes involved in RNA-processing and basal regulation of transcription from RNA polymerase II were differentially expressed [Additional file 8]. One very intriguing gene (An07g03760) was upregulated on maltose with same level of significance and fold difference as the most significant upregulated secretory pathway genes. It encodes a highly conserved homolog of the P100 EBNA-2 transcriptional co-activator, which is abundantly expressed in endo-and exocrine tissues in mammals $[35,36]$. The homolog of this gene was also higher expressed in T. reesei during secretion stress [37], indicating that this transcriptonal profile is conserved among filamentous fungi. Despite a high degree of conservation in all eukaryotic lineages no homolog is found in the yeast $S$. cerevisiae. Elements of some cellular functions, like protein secretion, may be more conserved between higher eukaryotes and filamentous fungi, compared to the in many ways reduced ascomycete, $S$. cerevisiae. Consequently, a better understanding of processes and regulation of protein secretion in filamentous fungi may require comparison to secretory cells of higher eukaryotes.

\section{Conclusion}

We provide evidence for carbon source induced, growth rate independent and concerted transcriptional regulation of genes encoding proteins in the secretory pathway in $A$. 
niger. We hypothesize that the fungal cell has a principal mechanism for co-ordinated regulation of basal anabolic pathways to modulate capacity of the secretory pathway. The main perspectives of our results are identification of putative regulatory elements, which coordinate expression of genes involved in protein synthesis and secretion, and increased understanding of transcriptional regulation of the secretory pathway in more normal physiological conditions. We show that an appropriate experimental approach allows study of subtle changes in expression of genes involved in important cellular processes. Furthermore, studies of lower eukaryotes, like A. niger, can be used to study functions and processes which are conserved in higher eukaryotes, with advantages in ease of propagation and ability to control growth and environmental variables.

\section{Methods}

\section{Strains and inoculum}

Aspergillus niger AB94-85 [38] and ABGT1026 [39] were cultivated in triplicate xylose- and maltose-limited chemostat cultures. Both strains are derived from N400 (= NRRL3, ATCC9029, CBS120.49).

Conidia for inoculation of bioreactor cultures were harvested from solidified Complete Medium (CM), which contained (per liter): $6.0 \mathrm{~g} \mathrm{NaNO}_{3}, 1.5 \mathrm{~g} \mathrm{KH}_{2} \mathrm{PO}_{4}, 0.5 \mathrm{~g}$ $\mathrm{KCl}, 0.5 \mathrm{~g} \mathrm{Mg} \mathrm{SO} \cdot \cdot 7 \mathrm{H}_{2} \mathrm{O}, 1.0 \mathrm{~g}$ casamino acids, 5.0 g yeast extract, $20 \mathrm{~g}$ agar and $1 \mathrm{ml}$ trace metal solution. The trace metal solution contained per liter, $10 \mathrm{~g}$ EDTA, $4.4 \mathrm{~g}$ $\mathrm{ZnSO}_{4} \cdot 7 \mathrm{H}_{2} \mathrm{O}, 1.01 \mathrm{~g} \mathrm{MnCl}_{2} \cdot 4 \mathrm{H}_{2} \mathrm{O}, 0.32 \mathrm{~g} \mathrm{CoCl}_{2} \cdot 6 \mathrm{H}_{2} \mathrm{O}$, $0.315 \mathrm{~g} \mathrm{CuSO}_{4} \cdot 5 \mathrm{H}_{2} \mathrm{O}, 0.22 \mathrm{~g}\left(\mathrm{NH}_{4}\right)_{6} \mathrm{Mo}_{7} \mathrm{O}_{24} \cdot 4 \mathrm{H}_{2} \mathrm{O}$, $1.47 \mathrm{~g} \mathrm{CaCl}_{2} \cdot 2 \mathrm{H}_{2} \mathrm{O}$ and $1 \mathrm{~g} \mathrm{FeSO}_{4} \cdot 7 \mathrm{H}_{2} \mathrm{O}$ (modified from composition given by Vishniac and Santer [40]). $\mathrm{pH}$ of $\mathrm{CM}$ was adjusted to 5.8 with $\mathrm{NaOH}$ and autoclaved. The major carbon source, xylose, was autoclaved separately and added to give a final concentration of $1 \%(\mathrm{w} / \mathrm{v})$. Conidia from a $-80^{\circ} \mathrm{C}$ stock culture were spread over moist sterile filter paper discs, which were placed on CM plates. Filter paper discs facilitate spore harvest and increase yield of conidia. The solid medium cultures were incubated for three days at $30^{\circ} \mathrm{C}$ and then for five to seven days at $25^{\circ} \mathrm{C}$ to enhance conidiation. Spore plates were stored for no more than six months at $4{ }^{\circ} \mathrm{C}$. Conidia were harvested from filter paper discs with a sterile detergent solution containing $0.05 \%(\mathrm{w} / \mathrm{v})$ Tween 80 and $0.9 \%(\mathrm{w} /$ v) $\mathrm{NaCl}$.

\section{Continuous cultivation}

Carbon-limited chemostat cultures were performed in a Variomixing Bioreactor [41]. This bioreactor was designed especially for cultivation of filamentous microorganisms, which have a tendency to adhere to and grow on surfaces. The Variomixing Bioreactor possesses a number of features, which reduce biomass adhesion and wall growth, and thus maintains high culture homogeneity during prolonged cultivation of filamentous fungi. A more detailed description of the Variomixing Bioreactor and associated equipment used for continuous cultivation is available elsewhere [41,42]. The medium for batch and continuous cultivation was Minimal Medium and contained per liter: $4.5 \mathrm{~g} \mathrm{NH}_{4} \mathrm{Cl}, 1.5 \mathrm{~g} \mathrm{KH}_{2} \mathrm{PO}_{4}, 0.5 \mathrm{KCl}, 0.5 \mathrm{MgSO}_{4} \cdot 7 \mathrm{H}_{2} \mathrm{O}$ and $1 \mathrm{ml}$ trace metal solution. $0.01 \%$ polypropyleneglycol (PPG 2000, Fluka Chemika) was added to the medium used for continuous cultivation as antifoam agent. The final cell density limiting (growth-limiting) substrate was $7.5 \mathrm{~g}$ xylose or maltose (monohydrate) per liter. Carbon sources were heat sterilized separately from the Minimal Medium. During cultivation, temperature was set at $30^{\circ} \mathrm{C}$ and at $\mathrm{pH} 3$, and kept constant by computer controlled addition of $2 \mathrm{M} \mathrm{NaOH}$. Acidification of the culture broth was used as an indirect measure for growth [43]. Dissolved oxygen tension was always above $40 \%$ of air saturation.

Batch cultivation was initiated with inoculation of 4.3 liter minimal medium with $10^{9}$ conidia liter $^{-1}$. Germination was induced by addition of $0.003 \%(\mathrm{w} / \mathrm{w})$ yeast extract. During the first six hours of cultivation the culture was aerated (air flow $=1 \mathrm{l} \mathrm{min}^{-1}$ ) through the headspace of the reactor and stirrer speed kept low at $450 \mathrm{rpm}$ to avoid exhaust of the hydrophobic conidia. After six hours and germination of most conidia (now hydrophilic), air was sparged into the culture broth, mixing was intensified (750 rpm) for more efficient oxygen transfer and 0.01\% (v/v) PPG was added.

Xylose was the growth-limiting substrate in the batch culture and during the first five residence times of chemostat cultivation. Continuous cultivation was started after 80 mmol of $\mathrm{NaOH}$ had been added to the batch culture ( $80 \%$ of the xylose exhausted or appr. $3.5 \mathrm{~g}$ dry weight biomass formed per kg culture). The dilution rate (D) was set to $0.16 \mathrm{~h}^{-1}$, which corresponds to $80 \%$ and $60 \%$ of the maximum specific growth rate $\left(\mu_{\max }\right)$ on xylose $\left(\approx 0.20 \mathrm{~h}^{-}\right.$ $1)$ and maltose $\left(\approx 0.25 \mathrm{~h}^{-1}\right)$, respectively. After five residence times $(\approx 32 \mathrm{~h})$, the xylose-containing influent medium was replaced with maltose-containing medium. Continuous cultivation was performed for additional five residence times on maltose. Steady-state, a situation where the specific growth rate $(\mu)$ is equal to the dilution rate (D), was defined by constant alkali addition rate and constant $\mathrm{CO}_{2}, \mathrm{O}_{2}$, biomass and substrate concentrations after four residence times.

Samples were drawn regularly to monitor culture growth and for determination of steady-state. A special sampling device was used to sample up to $100 \mathrm{ml}$ culture broth in less than a second. The technical principle of the sampling device was previously described [44]. All samples were 
quickly frozen in liquid nitrogen. Culture filtrate used in substrate and protein determinations was obtained by rapid filtration of culture broth through cotton wool before freezing. $10 \mathrm{mM} \mathrm{NaN}_{3}$ was used to conserve samples for determination of organic carbon. Mycelium harvested during steady-state was used in gene expression studies. Mycelium was separated from culture broth by filtration through sintered glass and frozen in liquid nitrogen within $15 \mathrm{sec}$ after sampling.

\section{Determination of substrate and biomass concentration}

Xylose was determined by the modified orcinol reaction described by Standing et al. [45]. Residual maltose and glucose (degradation product) was determined enzymatically as glucose, after incubation of culture filtrate with added a-glucosidase (EC 3.2.1.20) [46]. Glucose was determined according to the method of Bergmeyer et al. [47] with a slight modification; $250 \mathrm{mM}$ triethanolamine (TEA) was used as buffer ( $\mathrm{pH} 7.5$ ). Dry weight biomass concentration was determined by weighing freeze dried mycelium separated from a known mass of culture broth. Culture broth was filtered through GF/C glass microfibre filter (Whatman).

\section{Carbon recovery}

Influent carbon (continuous culture) was accounted for by carbon-analysis of effluent culture broth (biomass and filtrate) and measurement of $\mathrm{CO}_{2}$ in exhaust gas. Biomass carbon was determined according to the method of Kristensen and Andersen [48]. The gas composition of dry mycelium oxidized at $1020^{\circ} \mathrm{C}$ was determined by gas chromatography with a Carlo Erba 1100EA Elemental Analyzer using acetanilide as standard. Organic carbon in culture filtrate was determined with a TOC-5000 Total Organic Carbon Analyzer (Shimadzu). Malonic acid was used as standard and samples diluted with Millipore water. Content of $\mathrm{CO}_{2}$ and $\mathrm{O}_{2}$ was measured in exhaust gas of the bioreactor with a Binos $100 \mathrm{M}$ gas analyzer (Rosemount Analyticals).

\section{Protein determination}

Bio-Rad Protein Assay (microassay procedure) was used to determine extracellular protein concentration in culture filtrate. Bovine serum albumin was used as standard.

\section{RNA isolation and quality control}

Total RNA was isolated by modified Trizol extraction. Frozen ground mycelium $(\approx 100 \mathrm{mg}$ ) was directly suspended in $500 \mu \mathrm{L}$ Trizol reagent (Invitrogen) and vortexed vigorously for 5-10 min. After centrifugation for $5 \mathrm{~min}$ at $13,000 \mathrm{rpm}, 450 \mu \mathrm{L}$ of the supernatant was transferred to a new tube. Chloroform $(90 \mu \mathrm{L})$ was added and extraction continued as recommended in the Trizol protocol. RNA was purified on NucleoSpin RNA II columns (MacheryNagel), including a DNaseI digestion step. RNA was eluted in $60 \mu \mathrm{L}$ miliQ water. RNA quantity and quality was determined on a Nanodrop spectrophotometer and integrity was tested on an Agilent 2100 Bioanalyser.

\section{Micro-array analysis}

Probe synthesis and fragmentation were performed at ServiceXS (Leiden, The Netherlands) according to Affymetrix protocol [49]. DSM (Delft, The Netherlands) proprietary A. niger genechips were hybridised, washed, stained and scanned according to Affymetrix protocol [49]. The 3' to 5 ' signal ratio of probe sets of internal control genes, like gpdA (glyceraldehyde-3-phosphatedehydrogenase), pkiA (pyruvatekinase), $h x k$ (hexokinase) and $\gamma$-actin, were below 3 on all arrays (12 arrays). Percentage of probe sets evaluated as present (\%P of 14,555 probe sets) was 41 on xylose ( 6 arrays) and 39 on maltose ( 6 arrays).

\section{Normalization, filtering, statistical significance and comparisons}

Handling of microarray results and statistical comparisons were performed with GeneSpring (Silicon Genetics, 2004 ) software. Genes with detection call Present or Marginal in at least one of three replicate measurements were accepted as expressed and used in further analyses. Raw signal values were normalized Per-chip to $50^{\text {th }}$ percentile and Per-gene to median prior to comparison of conditions. Four experimental conditions were compared (maltose- and xylose-limited chemostat cultures of two strains); each condition represented by independent triplicate measurements. Replicate variation of transcript levels was characterized as $\mathrm{CV}$ of $25^{\text {th }}, 50^{\text {th }}, 75^{\text {th }}$ and $90^{\text {th }}$ percentiles $(\mathrm{P})$ of expressed genes with least variable signal intensities. Xylose-limited cultures (AB94-85/ ABGT1026): P25 =0.08/0.07, P50 =0.12/0.12, P75 = $0.19 / 0.18$ and $\mathrm{P} 90=0.28 / 0.27$. In maltose-limited cultures the corresponding values were $0.13 / 0.10,0.19 / 0.15$, $0.27 / 0.22$ and $0.37 / 0.31$. Genes expressed differentially on carbon source were identified by 2 -way ANOVA (variances were not assumed equal) with a cut-off p-value of 0.005. Benjamini Hochberg False Discovery Rate [50], FDR, was $<0.05$ for genes identified as differentially expressed. Fold change of gene expression from xylose to maltose (maltose/xylose) was calculated for genes with significantly different expression on the two carbon sources.

\section{Authors' contributions}

TRJ carried out chemostat cultivaton, physiological and transcriptomic analyses and wrote the manuscript. TG extracted and purified RNA, carried out initial Northern blot analyses and participated in transcriptomic analysis. AFJR, CvdH and JJLI were involved in writing the manuscript. All authors contributed to design of the experiments and discussion of the results.

All authors read and approved the final manuscript 


\section{Additional material}

\section{Additional file 1}

Signal intensities and detection calls. Transcript profiles of 12 steady states from xylose-or maltose-limited chemostat cultures.

Click here for file

[http://www.biomedcentral.com/content/supplementary/14712164-10-44-S1.xls]

\section{Additional file 2}

Steady state transcription of genes in the putative fumonisin gene cluster. Steady state transcription of genes in the putative fumonisin gene cluster.

Click here for file

[http://www.biomedcentral.com/content/supplementary/14712164-10-44-S2.pdf]

\section{Additional file 3}

All genes differentially expressed between maltose- and xylose-limited cultures. 2-way ANOVA applied to isolate effect of carbon source, significance: $p<0.005 ; 1,247$ genes identified as differentially expressed. Click here for file

[http://www.biomedcentral.com/content/supplementary/14712164-10-44-S3.xls]

\section{Additional file 4}

Northern blot analyses. Northern blot analyses of glaA, bipA and actin expression in xylose- and maltose-limited chemostat cultures.

Click here for file

[http://www.biomedcentral.com/content/supplementary/14712164-10-44-S4.pdf]

\section{Additional file 5}

Funcat 01.06 Lipid, fatty-acid and isoprenoid metabolism. Subset of all differentially expressed genes (Additional file 3).

Click here for file

[http://www.biomedcentral.com/content/supplementary/14712164-10-44-S5.xls]

\section{Additional file 6}

Funcat 05 Protein synthesis. Subset of all differentially expressed genes (Additional file 3)

Click here for file

[http://www.biomedcentral.com/content/supplementary/1471-

2164-10-44-S6.xls]

\section{Additional file 7}

HacA transcription and processing. RT-PCR of HacA transcripts from xylose- or maltose-limited steady state cultures of A. niger AB94-85 (culture \#96) and ABGT1026 (culture \#97).

Click here for file

[http://www.biomedcentral.com/content/supplementary/14712164-10-44-S7.pdf]

\section{Additional file 8}

Funcat 04 Transcription. Subset of all differentially expressed genes (Additional file 3).

Click here for file

[http://www.biomedcentral.com/content/supplementary/1471-

2164-10-44-S8.xls]

\section{Acknowledgements}

We thank Jack T. Pronk and V. Meyer for their comments and suggestions to improve the manuscript, and Erling Knudsen, Mark Arentshorst and Rasmus Skytte for technical assistance. The research group of C.A.M.J.J. van den Hondel is part of the Kluyver Centre for Genomics of Industrial Fermentation, which is supported by the Netherlands Genomics Initiative.

\section{References}

I. De Vries RP, Visser J: Aspergillus enzymes involved in degradation of plant cell wall polysaccharides. Microbiol Mol Biol Rev 2001, 65:497-522.

2. Yuan XL, Goosens C, Kools H, Maarel MJ van der, Hondel CA van den, Dijkhuizen L, Ram AF: Database mining and transcriptional analysis of genes encoding inulin-modifying enzymes of Aspergillus niger. Microbiol 2006, I52:306 I-3073.

3. Pel HJ, de Winde JH, Archer DB, Dyer PS, Hofmann G, Schaap PJ, Turner G, de Vries RP, Albang R, Albermann K, Andersen MR, Bendtsen JD, Benen JA, Berg $M$ van den, Breestraat $S$, Caddick MX, Contreras R, Cornell M, Coutinho PM, Danchin EG, Debets AJ, Dekker P, van Dijck PW, van Dijk A, Dijkhuizen L, Driessen AJ, d'Enfert C, Geysens S, Goosen C, Groot GS, de Groot PW, Guillemette T, Henrissat $B$, Herweijer M, Hombergh JP van den, Hondel CA van den, Heijden RT van der, Kaaij RM van der, Klis FM, Kools HJ, Kubicek CP, van Kuyk PA, Lauber J, Lu X, Maarel MJ van der, Meulenberg R, Menke H, Mortimer MA, Nielsen J, Oliver SG, Olsthoorn M, Pal K, van Peij NN, Ram AF, Rinas U, Roubos JA, Sagt CM, Schmoll M, Sun J, Ussery D, Varga J, Vervecken W, Vondervoort PJ van de, Wedler $H$, Wösten $\mathrm{HA}$, Zeng AP, van Ooyen AJ, Visser J, Stam H: Genome sequencing and analysis of the versatile cell factory Aspergillus niger CBS 5 I3.88. Nat Biotechnol 2007, 25:22I-23I.

4. Andersen MR, Vongsangnak W, Panagiotou G, Salazar MP, Lehmann L, Nielsen J: A trispecies Aspergillus microarray: comparative transcriptomics of three Aspergillus species. Proc Natl Acad Sci USA 2008, 1 8:4387-4392.

5. Pitt Jl: Toxigenic fungi: which are important? Med Mycol 2000, 38: $17-22$.

6. Cary JW, Ehrlich K: Aflatoxigenicity in Aspergillus : molecular genetics, phylogenetic relationships and evolutionary implications. Mycopathol 2006, I62:167-I77.

7. Jørgensen TR: Identification and toxigenic potential of the industrially important fungi, Aspergillus oryzae and Aspergillus sojae. J Food Prot 2007, 70:2916-2934.

8. Schuster E, Dunn-Coleman N, Frisvad JC, van Dijck PWM: On the safety of Aspergillus niger - a review. Appl Microbiol Biotechnol 2002, 59:426-435.

9. Frisvad JC, Smedsgaard J, Samson RA, Larsen TO, Thrane U: Fumonisin $\mathbf{B}_{2}$ production by Aspergillus niger. J Agric Food Chem 2007, 55:9727-9732.

10. Conesa A, Punt PJ, van Luijk N, Hondel CAMJJ van den: The secretion pathway in filamentous fungi: a biotechnological view. Fungal Genet Biol 200I, 33:155-171.

II. Helenius A, Aebi M: Roles of N-linked glycans in the endoplasmic reticulum. Annu Rev Biochem 2004, 73:1019-1049.

12. Sato K, Nakano A: Mechanisms of COPII vesicle formation and protein sorting. FEBS Lett 2007, 581:2076-2082.

13. van Anken E, Braakman I: Versatility of the endoplasmic reticulum protein folding factory. Crit Rev Biochem Mol Biol 2005, 40:191-228.

14. Wallis GLF, Swift RJ, Hemming FW, Trinci APJ, Peberdy JF: Glucoamylase overexpression and secretion in Aspergillus niger : analysis of glycosylation. Biochim Biophys Acta 1999, 1472:576-586.

15. Guillemette T, van Peij NNME, Goosen T, Lanthaler K, Robson GD, Hondel CAMJ van den, Stam H, Archer DB: Genomic analysis of the secretion stress response in the enzyme-producing cell factory Aspergillus niger. BMC Genomics 2007, 8: 158.

16. Piper MDW, Daran-Lapujade P, Bro C, Regenberg B, Knudsen S, Nielsen J, Pronk JT: Reproducibility of oligonucleotide microarray transcriptome analyses - an interlaboratory comparison using chemostat cultures of Saccharomyces cerevisiae. J Biol Chem 2001, 277:3700I-37008.

17. Ruepp A, Zollner A, Maier D, Albermann K, Hani J, Mokrejs M, Tetko I, Güldener U, Mannhaupt G, Münsterkötter M, Mewes HW: The FunCat, a functional annotation scheme for systematic clas- 
sification of proteins from whole genomes. Nucleic Acids Res 2004, 32:5539-5545.

18. Yuan XL, Kaaij RM van der, Hondel CA van den, Punt PJ, Maarel MJ van der, Dijkhuizen L, Ram AF: Aspergillus niger genome-wide analysis reveals a large number of novel alpha-glucan acting enzymes with unexpected expression profiles. Mol Genet Genomics 2008, 279:545-56I.

19. van Peij NN, Gielkens MM, de Vries RP, Visser J, de Graaff LH: The transcriptional activator $X \ln R$ regulates both xylanolytic and endoglucanase gene expression in Aspergillus niger. Appl Environ Microbiol 1998, 64:3615-3619.

20. Wang X, Devaiah SP, Zhang W, Welti R: Signaling functions of phosphatidic acid. Prog Lipid Res 2006, 45:250-278.

21. Punt PJ, van Gemeren IA, Drint-Kuijvenhoven J, Hessing JG, van Mijlwijk-Harteveld GM, Beijersbergen A, Verrips CT, Hondel CA van den: Analysis of the role of the gene bipA, encoding the major endoplasmic reticulum chaperone protein in the secretion of homologous and heterologous proteins in black Aspergilli. Appl Microbiol Biotechnol 1998, 50:447-454.

22. Ngiam C, Jeenes DJ, Punt PJ, Hondel CAMJ] van den, Archer DB: Characterization of a foldase, protein disulfide isomerase $A$, in the protein secretory pathway of Aspergillus niger. Appl Environ Microbiol 2000, 66:775-782.

23. Shoji J, Arioka M, Kitamoto K: Dissecting cellular components of the secretory pathway in filamentous fungi: insights into their application for protein production. Biotechnol Lett 2008 , 30:7-14.

24. Saloheimo M, Lund M, Penttilä ME: The protein disulfide isomerase gene of the fungus Trichoderma reesei is induced by endoplasmic reticulum stress and regulated by the carbon source. Mol Gen Genet 1999, 262:35-45

25. Webb GC, Akbar MS, Zhao C, Steiner DF: Expression profiling of pancreatic $\beta$ cells: glucose regulation of secretory and metabolic pathway genes. Proc Natl Acad Sci USA 2000, 7:5773-5778.

26. Shaffer AL, Shapiro-Shelef M, Iwakoshi NN, Lee AH, Qian SB, Zhao $\mathrm{H}, \mathrm{Yu} X$, Yang L, Tan BK, Rosenwald A, Hurt EM, Petroulakis E, Sonenberg N, Yewdell JW, Calame K, Glimcher LH, Staudt LM: Xbp I, downstream of Blimp-I, expands the secretory pathway apparatus and other organelles, and increases protein synthesis in plasma membrane cell differentiation. Immunity 2004, $21: 81-93$.

27. Gass JN, Gifford NM, Brewer JW: Activation of an unfolded protein response during differentiation of antibody-secreting $B$ cells. J Biol Chem 2002, 277:49047-49054.

28. Travers KJ, Patil CK, Wodicka L, Lochhart DJ, Weissmann JS, Walter $P$ : Functional and genomic analyses reveal an essential coordination between the unfolded protein response and ERassociated degradation. Cell 2000, I0I:249-258.

29. Kitama Y, Ishiwata-Kitama Y, Yamada S, Kohno K: Yeast unfolded protein response pathway regulates expression of genes for anti-oxidative stress and cell surface proteins. Genes Cells 2006, I I:59-69.

30. Chang HJ, Jesch SA, Gaspar ML, Henry SA: Role of the unfolded protein response pathway in secretory stress and regulation of inol expression in Saccharomyces cerevisiae. Genetics 2004 , 168:1899-1913.

3I. Goodman AG, Smith JA, Balachandran S, Perwitasari O, Proll SC, Thomas MJ, Korth Mj, Barber GN, Schiff LA, Katze MG: The cellular protein $\mathrm{P} 58^{\mathrm{IPK}}$ regulates influenza virus $\mathrm{mRNA}$ translation and replication through a PKR-mediated mechanism. J Virol 2007, 8 I:222I-2230.

32. Tvegård T, Soltani H, Skjølberg HC, Krohn M, Nilssen EA, Kearsey $B G$, Grallert $B$, Boye $E$ : A novel checkpoint mechanism regulating the GI/S transition. Genes Dev 2007, 21:649-654.

33. Tournu H, Tripathi G, Bertram G, Macaskill S, Mavor A, Walker L, Odds FC, Gow NAR, Brown AJP: Global role of the protein kinase $\mathbf{G c n} 2$ in the human pathogen Candida albicans. Eukaryotic Cell 2005, 4:1687-1696.

34. Patil CK, Li H, Walter P: Gcn4p and novel upstream activating sequences regulate targets of the unfolded protein response. PLOS biol 2004, 2:e246.

35. Broadhurst MK, Lee RSF, Hawkins S, Wheeler T: The pI 00 EBNA2 coactivator: a highly conserved protein found in a range of exocrine and endocrine cells and tissues in cattle. Biochim Biophys Acta 2005, I68 I: | 26- I33.
36. Keenan TW, Winter S, Rackwitz HR, Heid HW: Nuclear coactivator protein pl00 is present in endoplasmic reticulum and lipid droplets of milk secreting cells. Biochim Biophys Acta 2000 , I 523:84-90.

37. Arvas M, Pakula T, Lanthaler K, Saloheimo M, Valkonen M, Suortti T, Robson G, Penttilä M: Common features and interesting transcriptional responses to secretion stress in the fungi Trichoderma reesei and Saccharomyces cerevisiae. BMC Genomics 7:32.

38. Van Gorcom RFM: Analysis of gene expression in Aspergillus. In PhD thesis University of Amsterdam; 1997.

39. Frenken LG, Hessing JG, Hondel CA van den, Verrips CT: Recent advances in the large-scale production of antibody fragments using lower eukaryotic microorganisms. Res Immunol 1998, 149:589-599.

40. Vishniac W, Santer M: The thiobacilli. Bacteriol Rev 1957, 21:195-213

41. Larsen B, Rask Poulsen B, Eriksen NT, Lønsmann Iversen J]: Homogeneous batch cultures of Aspergillus oryzae by elimination of wall growth in the Variomixing bioreactor. Appl Microbiol Biotechnol 2004, 64: 192-198.

42. Jørgensen TR, vanKuyk PA, Poulsen BR, Ruijter GJG, Visser J, Iversen $J \mathrm{~J}:$ Glucose uptake and growth of glucose-limited chemostat cultures of Aspergillus niger and a disruptant lacking MstA, a high-affinity glucose transporter. Microbiology 2007, I53:1963-1973.

43. Iversen JJL, Thomsen JK, Cox RP: On-line growth measurements in bioreactors by titrating metabolic proton exchange. Appl Microbiol Biotechnol 1994, 42:256-262.

44. Iversen JJL: A rapid sampling valve with minimal dead space for laboratory scale fermenters. Biotechnol Bioeng 1981, 23:437-440.

45. Standing CN, Fredrickson AG, Tsuchiya HM: Batch- and continuous-culture transients for two substrate systems. Appl Microbiol 1972, 23:354-359.

46. Beutler HO: Maltose. In Methods of Enzymatic Analysis Volume VI. Edited by: Bergmeyer HU. Weinheim: Verlag Chemie; 1983: I 19-126.

47. Bergmeyer HU, Bernt E, Schmidt F, Stork H: Glucose. In Methods of Enzymatic Analysis Volume 3. Edited by: Bergmeyer HU. New York: Academic Press; 1974:1 196-1201.

48. Kristensen E, Andersen FØ: Determination of organic carbon in marine sediments: a comparison of two $\mathrm{CHN}$-analyzer methods. J Exp Mar Biol Ecol 1987, 109:15-23.

49. GeneChip Expression Analysis Technical Manual Affymetrix, inc. 2002.

50. Benjamini Y, Hochberg Y: Controlling the False Discovery Rate: a practical and powerful approach to multiple testing. J Royal Stat Soc B 1995, 57:289-300.

Publish with Biomed Central and every scientist can read your work free of charge

"BioMed Central will be the most significant development for disseminating the results of biomedical research in our lifetime. "

Sir Paul Nurse, Cancer Research UK

Your research papers will be:

- available free of charge to the entire biomedical community

- peer reviewed and published immediately upon acceptance

- cited in PubMed and archived on PubMed Central

- yours - you keep the copyright 